\title{
국내 도시개발 분야 공적개발원조(ODA) 사업의 방향성
}

- 지속가능개발목표(SDGs)와 KOICA 도시 마스터플랜 사례를 중심으로

목 차

I. 들어가며

II. 지속가능개발목표(SDGs)와 도시개발 분야 ODA 추진 동향

1. SDGs와 도시개발 관련 국제 동향

1) 지속가능개발목표(SDGs)

2) 유엔해비타트(UN-HABITAT)의 지속가능한 도시화 추진전략

3) 세계은행(WB)의 도시개발 관련 추진 정책

4) 아시아개발은행(ADB)의 도시개발 관련 추진 정책

2. 국내 도시개발 분야 ODA 사업 현황

III. KOICA 도시 마스터플랜의 성과와 후속 사업 연계 시례

1. 베트남 후에시 마스터플랜 사업 : KOICA

1) 베트남 공간계획 관련 법률 및 정책

2) 사업개요 및 추진배경

3) 도시 마스터플랜 주요 내용

4) 주요 성과 및 시사점

2. 후에시 마스터플랜 연계사업 : KOICA, ADB

1) KOICA 후속 사업 : 향강 연안 상세계획 및 시범사업 상세설계

2) 다자간 개발은행과의 협력사업: ADB Green Cities Project

IV. 나가며

참고문헌 


\section{요 약}

지속가능개발목표(SDGs)는 2030년까지 시행해야 할 범지구적 목표로서, 국제사회 와 개별 국가가 나아가야 하는 방향을 제시하는 새로운 정책의 패러다임이다. 기존 $\mathrm{MDGs}$ 와 달리 SDGs에서는 17 개 목표 중 도시개발 분야를 11 번째 목표(SDG 11. 포용적이고 안전하며 회복력 있고 지속가능한 도시와 거주지 조성)로 격상시키고, 다양 한 분야에 걸친 이슈를 조율·조정하는 도시의 역할과 잠재력에 주목하였다. 또한 지속가 능한 사회로의 전환을 위한 중요한 기반으로서 도시개발 관련 기반의 확충을 요구하고 있다. 이에 따라 우리나라에서도 도시개발 분야에 대한 공적개발원조(ODA)의 방향성 을 재검토하고 구체화할 필요가 있다.

이 글에서는 SDGs와 함께 도시개발 분야 국제개발협력의 국내외 추진동향을 살펴보 고, $\mathrm{KOICA}$ 도시 마스터플랜 사업으로서 후속사업으로 연계 추진된 사례를 소개하였다. 우리나라 도시개발 분야 ODA 사업에 대한 시사점으로는 SDGs에 부합하는 도시개발 분야 $\mathrm{ODA}$ 사업 기획 및 세부전략 수립, $\mathrm{ODA}$ 사업의 파급효과를 고려한 지원 대상지역 의 전략적 선정, 후속사업 연계 추진을 대한 공공과 민간의 다각적 노력 등이 논의될 수 있다.

주제어: 지속가능개발목표(SDGs), 도시개발 분야 ODA, 도시 마스터플랜 


\section{I. 들어가며}

새천년개발목표(Millennium Development Goals, 이하 MDGs)가 2015년 만료되면서 국 제연합(United Nations, 이하 UN)은 17개 목표를 담은 지속가능개발목표(Sustainable

Development Goals, 이하 SDGs)를 발표하고 2030년까지 시행해야 할 범지구적 목표를 채택 하였다. SDGs는 전 세계적으로 국제사회와 개별 국가가 나아가야 하는 방향을 제시하는 새로 운 정책의 패러다임이다. MDGs에서는 빈곤과 기아의 퇴치와 보건이 주목적이었으나, SDGs 는 지속 가능한 사회로의 전환을 위한 중요한 기반으로서 도시를 이해하고 관련 기반을 확충할 것을 요구하고 있다. 기존 MDGs에서는 도시 이슈가 한 개의 하위목표로서 다루어졌다면, $\mathrm{SDGS}$ 에서는 도시문제를 주요 목표의 하나로 격상시킴과 동시에, 다양한 분야에 걸친 이슈를

조율, 조정하는 도시의 역할과 잠재성에 주목하고 있다(방설아.신유승, 2015). 이에 따라 우리 나라에서도 도시개발 분야에 대한 공적개발원조(Official Development Assistance, 이하 $\mathrm{ODA})$ 의 방향성을 재검토하고 구체화할 필요가 있다.

이 글에서는 SDGs와 함께 도시개발1) 분야 국제개발협력의 국내외 추진 동향을 살펴보고, 한국국제협력단(Korea International Cooperation Agency, 이하 KOICA) 도시 마스터플랜 사업으로서 후속 사업으로 연계 추진된 사례를 소개함으로써 주요 시사점을 논의하고자 한다.

1) $\mathrm{OECD} \mathrm{DAC에서} \mathrm{논의되는} \mathrm{‘도시개발} \mathrm{및} \mathrm{관리’는} \mathrm{다분야.} \mathrm{범분야} \mathrm{항목으로} \mathrm{분류되며,} \mathrm{통합적} \mathrm{도시개발} \mathrm{프로젝트,} \mathrm{지역개}$ 발 및 관리, 도시 인프라 및 서비스, 지방재정, 환경관리, 도시계획, 도시 재생 및 도시 주택, 토지정보시스템 등을 포함한다. 학술적 개념으로서 협의의 도시개발은 물리적 측면에서의 신도시 개발, 재개발과 같은 도시공간 개발을 의미하며, 광의의 도시개발은 도시 성장을 관리하고 도시 발전을 도모하기 위한 경제, 사회 등 모든 개발행위의 총체로 서 정의된다. 이 글에서는 $\mathrm{OECD} \mathrm{DAC}$ 의 도시개발 및 관리로서 도시개발 용어를 사용하고자 한다. 


\section{II. 지속가능개발목표(SDGs)와 도시개발 분야 ODA}

\section{SDGs와 도시개발 관련 국제 동향}

\section{1) 지속가능개발목표(SDGs)}

지속가능개발목표(SDGs)는 지속가능 발전을 이루기 위해 UN에서 제시한 보편적 행동 의 제로서, (1)빈곤 (2)기아 및 농업 (3)건강 (4)교육 (5)양성평등 (6)물 (7)에너지 (8)경제 (9)사회기반시 설 및 산업화 (10)불평등 (11)도시와 정주지 (12)소비 및 생산양식 (13)기후변화 (14)해양자원 (15)육상 생태계 (16사회 및 제도 (17)글로벌 파트너십 관련 17개 목표와 169개 세부목표로 구성되어 있다.

SDGs 17 개 목표 중 도시개발 분야는 11 번째 목표(포용적이고 안전하며 회복력 있고 지속가능 한 도시와 거주지 조성, Make cities and human settlements inclusive, safe, resilient and sustainable)에 집중되어 있다. 목표 11은 주택, 대중교통, 도시계획, 자연 및 문화유산, 재난 및 재해, 환경, 공공공간 및 녹지환경 등 도시 분야의 주요 지표를 담고 있으며, 하부전략으로 7 개의 실행목표(Action Targets, 11.1 11.7)와 3개의 이행수단(Means of Implementation, MOI, 11.a 11.c)이 제시되었다.

새천년개발목표(MDGs)에서 SDGs로 변화하면서 도시의 성장과 주거문제 해소를 위한 도 시개발이 주요 이슈로 다루어지고 있으며, 이로 인해 도시개발과 주거개선 등 도시개발 분야에 더 많은 투자가 이루어질 것으로 예상된다(<표 1>, <표 2> 참고).

〈표 1〉MDGs의 도시 관련 목표 (MDG 7)

\begin{tabular}{|c|c|c|}
\hline \multicolumn{2}{|c|}{ Goal 7. 환경의 지속가능성 추구 } & $\begin{array}{l}\text { 도시 } \\
\text { 관련성 }\end{array}$ \\
\hline 7.A & $\begin{array}{l}\circ \text { 지속가능개발의 원칙을 국가 정책 및 사업에 통합하고 환경자원의 손실을 } \\
\text { 회복한다. }\end{array}$ & $\times$ \\
\hline 7.B & ○ 특히 2010년까지 생태계의 손실률을 매우 감소시킨다. & $\times$ \\
\hline 7.C & $\begin{array}{l}\text { ○ 2015년까지 안전한 식수와 기본적 위생시설에 지속적으로 접근이 불가한 } \\
\text { 인구를 절반으로 줄인다. }\end{array}$ & $\times$ \\
\hline 7.D & ○ 2020년까지 최소 1 억 명의 도시 슬럼인구의 삶을 개선한다. & O \\
\hline
\end{tabular}

출처: 정지원·송지혜 (2014) 
〈표 2〉 SDGs의 도시 관련 목표 (SDG 11)

\begin{tabular}{|c|c|}
\hline \multicolumn{2}{|c|}{$\begin{aligned} \text { Goal 11. 지속가능한 도시와 커뮤니티 } \\
\text { 포용적이고 안전하며 회복력 있고 지속가능한 도시와 거주지 조성 }\end{aligned}$} \\
\hline 11.1 & 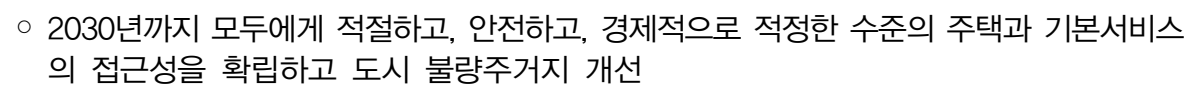 \\
\hline 11.2 & $\begin{array}{l}\text { ○ 2030년까지 도로안전 개선과 대중교통 확대를 통해 모든 사람들, 특히 취약계층과 여성, } \\
\text { 아동 그리고 장애인 및 노약자에게 안전하고, 적절한 비용 수준과, 높은 접근성의 지속가 } \\
\text { 능한 교통체계 제공 }\end{array}$ \\
\hline 11.3 & $\begin{array}{l}\text { 2030년까지 모든 국가의 포용적이고 지속가능한 도시화와 참여역량을 강화하고, 통합적 } \\
\text { 이고 지속가능한 인간 정주 계획과 관리 증진 }\end{array}$ \\
\hline 11.4 & $\circ$ 전 세계 문화와 자연 유산을 보호하고 지키기 위한 노력 강화 \\
\hline 11.5 & $\begin{array}{l}\circ \text { 2030년까지 빈곤층과 취약계층을 보호하면서 물 관련 재난을 포함한 자연재해로부터 } \\
\text { 발생하는 사망자 및 피해자 수를 현저히 줄이며 GDP 대비 경제적 손실 감소 }\end{array}$ \\
\hline 11.6 & $\begin{array}{l}\circ \text { 2030년까지 대기 질과 지자체 또는 다른 주체의 폐기물 관리에 대한 중점관리를 통해 } \\
\text { 인구 } 1 \text { 명당 도시에 미치는 환경의 부정적인 효과 감소 }\end{array}$ \\
\hline 11.7 & $\begin{array}{l}\text { ○ 2030년까지 특히 여성, 아동, 노인과 장애인을 고려한 포괄적이고 접근가능한 공공공간과 } \\
\text { 녹지환경을 조성함으로써 안전하고 보편적인 접근법 제공 }\end{array}$ \\
\hline 11.a & $\begin{array}{l}\circ \text { 국가개발계획 또는 지역개발계획 강화를 통해 도시와 도시주변부 지역 및 지방과의 경제 } \\
\text { 적, 사회적, 환경적 연계성 강화 지원 }\end{array}$ \\
\hline 11.b & $\begin{array}{l}\text { 2020년까지 통합, 효율적인 자원 활용, 기후변화 저감 및 적응, 재난에 대한 회복력을 } \\
\text { 지향하는 통합정책과 계획이 반영되고 적용된 도시 및 정주지의 수를 증가시키고 센다이 } \\
\text { 체재의 후속 논의에 발맞추어 모든 관리 수준에서 통합 재난위험관리 체제를 개발하고 } \\
\text { 실행 }\end{array}$ \\
\hline 11.c & $\begin{array}{l}\circ \text { 지역 자재를 활용한 지속가능하고 복원력 있는 건축물을 구축함에 있어, 재정적, 기술적 } \\
\text { 보조를 통한 최빈개발도상국 지원 }\end{array}$ \\
\hline
\end{tabular}

출처: 손동필·오성훈 (2016)

\section{2) 유엔해비타트(UN-HABITAT)의 지속가능한 도시화 추진전략}

유엔인간정주계획(United Nations Human Settlements Programme, 이하 UN-HABITAT) 은 지속가능한 도시 건설과 인류에 적절한 정주 공간을 제공하기 위해 설립된 $\mathrm{UN}$ 의 도시화 및 인간거주지 전담기관이다.

UN-HABITAT에서는 도시를 단순한 정주 공간이 아닌 지속가능 발전을 위한 경제, 사회, 환경적 현안의 해결책이자 새로운 동력으로 인식하고, 도시화 과정에서 발생하는 문제에 대한 해법과 지속가능개발목표(SDGs) 달성을 위한 실천방안을 논의하고 있다. UN-HABITAT에 서는 지속가능한 도시화를 위한 세 가지 핵심요소로서, 도시정책 및 법규, 도시계획 및 디자인, 도시 및 지방재정을 강조하고 있다(김성호, 2016)(<표 3>, <표 4> 참고). 
〈표 3〉 UN-HABITAT의 지속가능한 도시화를 위한 세 가지 핵심요소

\begin{tabular}{|c|c|}
\hline 도시정책 및 법규 & $\begin{array}{l}\text { 장기적으로 도시의 형태와 특징을 좌우하며, 도시의 질과 지속가능성에 } \\
\text { 영향을 미치는 공공공간과 공공시설에 관한 규정, 도시환경 및 건축물 } \\
\text { 관련 법규 등 도시개발 및 관리와 관련된 법과 규정 수립 }\end{array}$ \\
\hline 도시계획 및 디자인 & $\begin{array}{l}\text { ○ 사전에 잘 계획된 도시공간은 적정한 밀도와 기능적인 공간 배치, 질 } \\
\text { 높은 공공공간 및 공공시설 디자인, 짜임새 있는 가로패턴 등을 통해 } \\
\text { 규모의 경제 최적화와 사회적 다양성 촉진 }\end{array}$ \\
\hline 도시 및 지방재정 & $\begin{array}{l}\text { 국가적 차원에서의 지방재정 확충을 위한 세제와 예산 배분 시스템, 그 } \\
\text { 리고 지방정부의 효과적인 투자유치 등을 위한 혁신적인 정책과 재정계 } \\
\text { 획 등을 구축하여 공공서비스 제공을 위한 재원 확보 }\end{array}$ \\
\hline
\end{tabular}

출처: 김성호 (2016)

〈표 4〉 HABITAT III의 10대 정책의제

\begin{tabular}{|c|c|}
\hline 구분 & 주요 내용 \\
\hline $\begin{array}{l}\text { 도시에 대한 권리와 } \\
\text { 모든 사람들을 위한 도시 } \\
\text { (Right to the City and } \\
\text { Cities for all) }\end{array}$ & $\begin{array}{l}\circ \text { 도시가 제공하는 주택, 교통, 보건위생, 환경, 안전, 사회복지, 문화, 경제 } \\
\text { 적 기회 등 각종 서비스의 혜택을 받을 수 있는 권리 } \\
\circ \text { 도시자원 배분의 공간적 공정성 확보, 도시구성원들에게 정치적 참여 기 } \\
\text { 제 제공, 그들의 사회적, 경제적, 문화적 다양성 존중 }\end{array}$ \\
\hline $\begin{array}{l}\text { 사회문화적 도시 체제 } \\
\text { (Socio-Cultural Urban } \\
\text { Framework) }\end{array}$ & $\begin{array}{l}\circ \text { 모든 도시민을 사회적, 문화적으로 포용하고 지속가능하고 회복력 높은 } \\
\text { 발전을 고양하는 사회적 형태와 문화적 자산 개발 } \\
\circ \text { 사람과 장소가 중심이 되는 인간다운 또는 인도적인 도시 지향 }\end{array}$ \\
\hline $\begin{array}{l}\text { 정책(National } \\
\text { Olicies) }\end{array}$ & $\begin{array}{l}\circ \text { 도시계횝이 지방정부의 정책적 우선순위에서 밀리지 않도록 지원하며, } \\
\text { 지방정부의 계획능력 강화 } \\
\circ \text { 도시와 농촌 간 이분법적 접근방식에서 벗어나 도시에서 근교 지역, 농촌 } \\
\text { 에 이르는 연계(Urban-Rural Linkage) 전략 수립 }\end{array}$ \\
\hline $\begin{array}{l}\text { 도시 거버넌스, 역량, 제도 } \\
\text { 발전(Urban Governance, } \\
\text { Capacity and Institutional } \\
\text { Development) }\end{array}$ & $\begin{array}{l}\circ \text { 다양한 이해관계자의 참여로 구성되는 거버넌스에 빈곤층을 포함한 모든 } \\
\text { 사회적 약자가 참여 가능한 참여문화의 창달 강조 } \\
\text { 토지주택시장을 효과적으로 규제할 수 있는 법과 제도, 비공식 정착지나 } \\
\text { 관행적인 토지제도의 도시계획을 통한 공식화 }\end{array}$ \\
\hline $\begin{array}{l}\text { 지방재정 및 조세체계 } \\
\text { (Municipal Financing } \\
\text { and Local Fiscal } \\
\text { System) }\end{array}$ & $\begin{array}{l}\circ \text { 지방정부의 공공재 공급에 따른 세입과 세출 간의 불균형 해소를 위한 } \\
\text { 다양한 재원조달방식 도입 } \\
\text { 공공투자에 의해 상승한 지가분의 일부를 공공이 회수하는 토지 가치에 } \\
\text { 기반을 둔 재원조달(land-based financing)의 필요성 제기 }\end{array}$ \\
\hline $\begin{array}{l}\text { 도시공간전략 } \\
\text { (Urban Spatial } \\
\text { Strategies) }\end{array}$ & $\begin{array}{l}\circ \text { 도시 및 공간계회 설계, 도시토지, 도시-농촌 연계, 공공공간 등 공간적 } \\
\text { 물리적 차원의 도시계획 문제로 대두 } \\
\circ \text { 도시공간전략의 우선순위는 지속가능한 도시 형태를 만드는 데 있으며, } \\
\text { 압축적이고 연결성이 높은 도시공간 구조를 지향해야 함 }\end{array}$ \\
\hline $\begin{array}{l}\text { 도시경제개발전략 } \\
\text { (Urban Economic } \\
\text { Development Strategies) }\end{array}$ & $\begin{array}{l}\circ \text { 기업 비즈니스 환경 개선, 인적자본 투자, 기술개발 등 소프트웨어 분야에 } \\
\text { 서부터 대중교통 중심의 압축적 도시개발을 통한 사람, 상품, 서비스, 아 } \\
\text { 이디어의 연결성 강화 등 하드웨어 전략 제시 }\end{array}$ \\
\hline $\begin{array}{l}\text { 도시 생태와 회복력 } \\
\text { (Urban Ecology and } \\
\text { Resilience) }\end{array}$ & $\begin{array}{l}\circ \text { 압축도시 등의 형태로 효과적으로 도시가 계획, 관리되면 환경 부하를 } \\
\text { 저감시키는 등 지속가능성과 회복력 증진에 기여 가능 }\end{array}$ \\
\hline $\begin{array}{l}\text { 도시 서비스와 기술 } \\
\text { (Urban Services a }\end{array}$ & $\begin{array}{l}\text { 닁의 차원에서 모든 도시민이 기초적인 생활서비스와 이동 } \\
\text { 기반시설의 혜택을 향유해야 함 }\end{array}$ \\
\hline
\end{tabular}




\begin{tabular}{l|l}
\hline \multicolumn{1}{c|}{ 구분 } & \multicolumn{1}{c}{ 주요 내용 } \\
\hline Technology) & $\begin{array}{l}\text { 기술진보의 혜택이 사회적 약자를 비롯한 모든 계층에게 균등하게 돌아가 } \\
\text { 야 함 }\end{array}$ \\
\hline $\begin{array}{l}\text { 주택으로서 거주성을 갖기 위해 토지 권리 관계 확보, 기초 서비스 제공, } \\
\text { 적정 면적의 위생적이고 구조적으로 안전한 건물 등의 조건 충족 }\end{array}$ \\
$\begin{array}{l}\text { 저소득층 주거입지가 고용기반, 대중교통 접근성을 갖추어 실제 주거문제잭 } \\
\text { 를 해결할 수 있도록 토지이용, 기반시설, 교통, 환경 등과 통합적으로 } \\
\text { 접근해야 할 필요가 있음 }\end{array}$ \\
\hline
\end{tabular}

출처: 최막중 (2016)

\section{3) 세계은행(WB)의 도시개발 관련 추진 정책}

세계은행(World Bank, 이하 WB)은 급격한 도시화가 진행되는 개발도상국 도시 중 인구 50 만 이하의 중소도시 문제에 집중하고 있으며, 경제성장과 함께 나타나는 인구 과밀로 인한 문제를 해결하여 지속가능한 도시화를 추구하고 있다.

$\mathrm{WB}$ 는 도시 및 지역 정부 전략서(Urban and Local Government Strategy) 등의 장기전략 프레임워크를 수립하여 도시지역 지원의 지침으로 활용하고 있다. 2000년과 2009년 수립된 도시 및 지역 정부 전략서는 도시의 거주성(livability) 향상을 최우선 목표로 하며, 이를 달성하 기 위해 도시 제도, 도시와 빈곤, 도시의 경제성장, 도시계획·토지·주택, 도시환경·기후변화·재 난관리를 주요 이슈로 다루고 있다. 도시의 핵심요소인 제도와 관련된 활동으로는 도시 관리, 인프라, 거버넌스, 재정 등에 관련된 활동을 중점적으로 지원하고 있다(정지원·송지혜, 2014).

$\mathrm{WB}$ 는 정책 및 제도 개선, 재정 지원, 기술 지원 등 다양한 형태의 사업과 지원수단을 활용하 고 있으며, 도시계획 관련 추진 정책으로서 도시 주변지 개발, 공공 토지 관리, 토지수용 제도, 임대시장 지원, 도로명 주소 확대 등을 권고하고 있다(<표 5> 참고).

\section{〈표 5〉 세계은행(WB)의 도시계획 관련 추진정책}

\begin{tabular}{c|c}
\hline 추진정책 & 주요 내용 \\
\hline $\begin{array}{c}\text { 도시 주변지의 } \\
\text { 개발 }\end{array}$ & $\begin{array}{c}\text { ○ 정부와 지자체가 급속히 성장하는 도시 주변 지역의 토지를 매입하여 인프라 } \\
\text { 미개발로 인한 부정적 영향을 제도적으로 보호 }\end{array}$ \\
\hline 공공 토지 관리 & $\begin{array}{c}\text { 공공 토지자산 관리 및 사용을 위한 규칙과 결정 과정의 명확성, 관련 자산에 } \\
\text { 대한 정보 시스템 개선 }\end{array}$ \\
\hline $\begin{array}{c}\text { 부지와 서비스의 } \\
\text { 지속 }\end{array}$ & $\begin{array}{c}\text { 부지와 서비스를 위한 사업의 정부 역할 지속 및 공공 토지를 갖고 있는 정부들 } \\
\text { 에게는 직접적인 개입 }\end{array}$ \\
\hline $\begin{array}{c}\text { 경제적인 } \\
\text { 토지 취득 }\end{array}$ & $\begin{array}{c}\text { 토지 취득을 위한 자금 지원을 톻해 도로, 철도 네트워크의 개선 및 도시 주변 } \\
\text { 부 교통 연결과 중심부 수입 창출의 기회 제공 }\end{array}$ \\
\hline 임대시장 지원 & $\circ$ 도시 임대시장 관련 연구 및 기술 지원 \\
\hline 도로명 주소 확대 & $\circ$ 토지소유권, 도로명 부여 등의 행정적 도구 사용 확대와 토지소유권 등을 통한 \\
\hline
\end{tabular}

출처: 정지원·송지혜 (2014) 


\section{4) 아시아개발은행(ADB)의 도시개발 관련 추진 정책}

아시아개발은행(Asian Development Bank, 이하 ADB)은 장기전략 프레임워크인 Strategy 2020(2008), Urban Operational Plan 2012-2020(2012)을 통해 아시아 도시개발 이니셔티브 (Cities Development Initiative for Asia)를 수립하고, 특히 아시아 개발도상국의 중소도시 (secondary cities)를 대상으로 지속가능한 도시 발전을 위한 주요 정책으로 추진 중이다.

$\mathrm{ADB}$ 의 도시개발 이니셔티브는 환경성(environment), 경제성(economy), 형평성(equity) 측면에서 접근하여 Green Cities, Competitive Cities, Inclusive Cities를 주요 프로그램2)으 로 추진하고 있다 $<$ 표 $6>$ 참고 $)$.

〈표 6〉 아시아개발은행(ADB)의 도시개발 이니셔티브

\begin{tabular}{|c|c|c|}
\hline 구분 & 주요 내용 & 보고서 \\
\hline $\begin{array}{l}\text { Green } \\
\text { Cities }\end{array}$ & $\begin{array}{l}\circ \text { 도시의 주요 환경문제를 파악하고 녹색도시를 달성하기 위해 } \\
\text { 인프라 부문 전반에 대한 투자 우선순위 지정 } \\
\circ \text { 공공 및 민간 파트너와 함께 상수도, 폐수, 고체폐기물, 지역 } \\
\text { 냉난방, 도시교통(도로 포함) 및 에너지 효율에 대한 투자 지 } \\
\text { 원 }\end{array}$ & $\begin{array}{l}\text { ADE } \\
\text { Green Cities } \\
\text { Urban Deveoments seres }\end{array}$ \\
\hline $\begin{array}{c}\text { Competitive } \\
\text { Cities }\end{array}$ & $\begin{array}{l}\circ \text { 아시아 개발도상국의 경제적 어려움을 해소하고 포괄적인 성 } \\
\text { 장을 위한 전략적인 도시클러스터 경제개발 접근 시도 } \\
\circ \text { 정부, 기업, 공동체가 경쟁력 있는 도시 경제의 포괄적이고 } \\
\text { 지속가능한 개발을 지원하는데 사용할 수 있는 전략적 프레 } \\
\text { 임워크와 분석방법 제공 } \\
\circ \text { 도시 관리자, 이해관계자의 액션플랜 수립 및 우선 투자지역 } \\
\text { 결정 지원 }\end{array}$ & $\begin{array}{l}\text { Competitive Cities } \\
\text { in the 21st Century }\end{array}$ \\
\hline $\begin{array}{l}\text { Inclusive } \\
\text { Cities }\end{array}$ & $\begin{array}{l}\circ \text { 슬럼, 비공식 정착촌, 황폐한 도심 거주지 등의 개선과 기후변 } \\
\text { 화 및 자연재해에 취약한 빈민층 지원 우선 } \\
\circ \text { 살기 좋은 도시의 비전을 달성하기 위해 점진적인 토지 및 } \\
\text { 주택 개발과 쉼터를 제공할 수 있도록 자금 지원 }\end{array}$ & 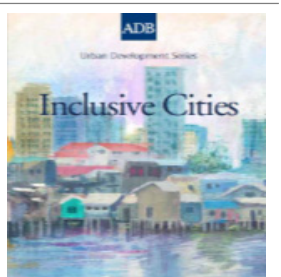 \\
\hline
\end{tabular}

출처: 아시아개발은행(ADB) 홈페이지 (www.adb.org) (접속일: 2017.11.27.)

2) $\mathrm{ADB}$ 사업은 프로그램(program)과 프로젝트(project)로 구분된다. 프로그램은 현지 협력대상국 개발을 위한 보다 큰 차원의 개발전략 개념이며, 프로그램에 의해 구체적인 개별 프로젝트가 수행된다. 


\section{2. 국내 도시개발 분야 ODA 사업 현황3)}

우리나라 국제개발협력사업 중 $\mathrm{KOICA}$ 에서 담당하는 무상원조사업의 도시개발 분야 사업추 진 현황을 살펴보고자 한다.

제 I 장

\section{제II장}

현재 KOICA 사업에서 도시개발 분야는 기술·환경·에너지 분야에 편입되어 있으며, 별도의 추진전략이 수립되어 있지 않다.4) 기술·환경·에너지 분야의 추진전략에 나타나는 도시개발 분야는 사회 인프라 구축 및 국토관리 역량강화를 통한 협력대상국의 자립 가능한 경제개발과 산업발전 촉진을 목표로, 국토정보 체계화, 도시계획 수립, 국토개발정책 수립, 국토종합개발 등의 프로그램을 추진하고 있다. 또한, 향후 기반시설 수요에 대한 통합적 접근과 실행력 있는 도시개발계획 수립을 통해 미래에 발생 가능한 충격을 미리 인지하여 회복력 있고 지속가능한 도시 및 정주지 조성을 지원한다는 전략을 수립하고 있다.

1991년부터 2015년까지 집행된 KOICA 무상원조사업의 전체 사업 규모는 1991년 2,300만 달러에서 2015년 5억6,000만 달러까지 꾸준히 증가하여 2015년 말 기준 누적금액은 약 49억 5,000 만 달러이다. 이 중 도시개발 분야에 해당하는 사업은 34 건, 지원금액은 약 9,400 만 달러 규모로서 2007년 이후 사업 개수와 규모가 확대되었다. 단위사업 당 사업비의 규모는 2014년 이후 약 500 만 달러 규모로 확대되었다(<그림 1>, <그림 2> 참고).

〈그림 1〉 KOICA 전체 사업 규모 (1999 2015)

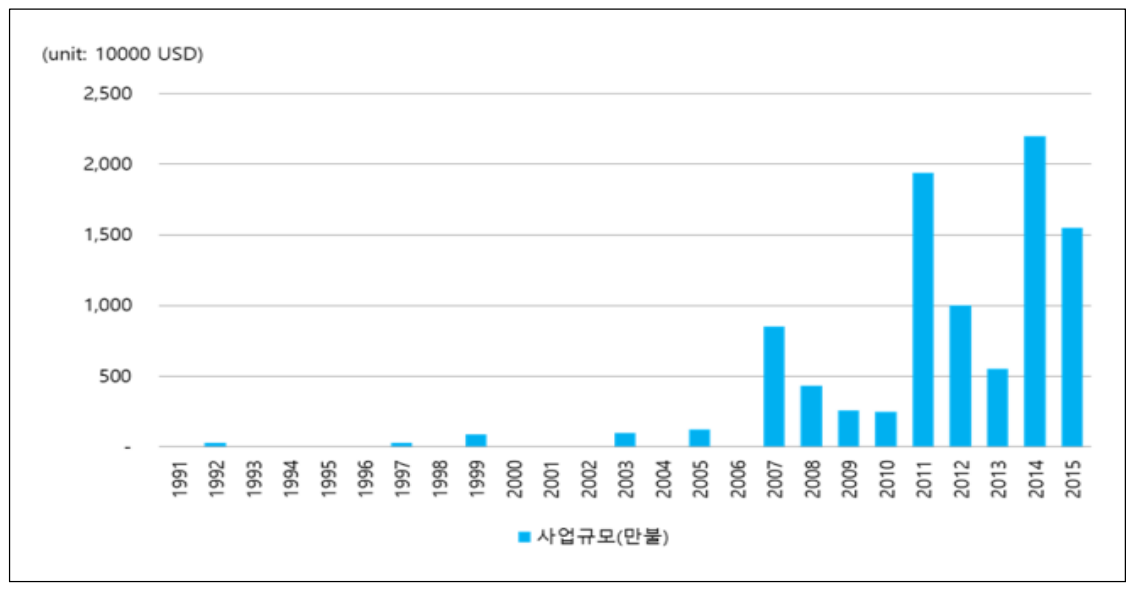

출처: KOICA 통계조회서비스 (http://stat.koica.go.kr) (접속일:2017.11.28.)

3) $\mathrm{KOICA}$ 통계조회서비스 및 $\mathrm{KOICA}$ 내부자료 참고 작성

4) $\mathrm{KOICA}$ 사업 분야는 현재 보건의료, 교육, 공공행정, 기술·환경·에너지, 농림수산, 긴급구호, 기타로 구분되어 있다. $\mathrm{KOICA}$ 내부적으로 2016년 말부터 도시개발 분야를 별도의 분야로 추진 검토 중이다. 
〈그림 2〉 KOICA 도시개발 분야 사업규모 (1999 2015)

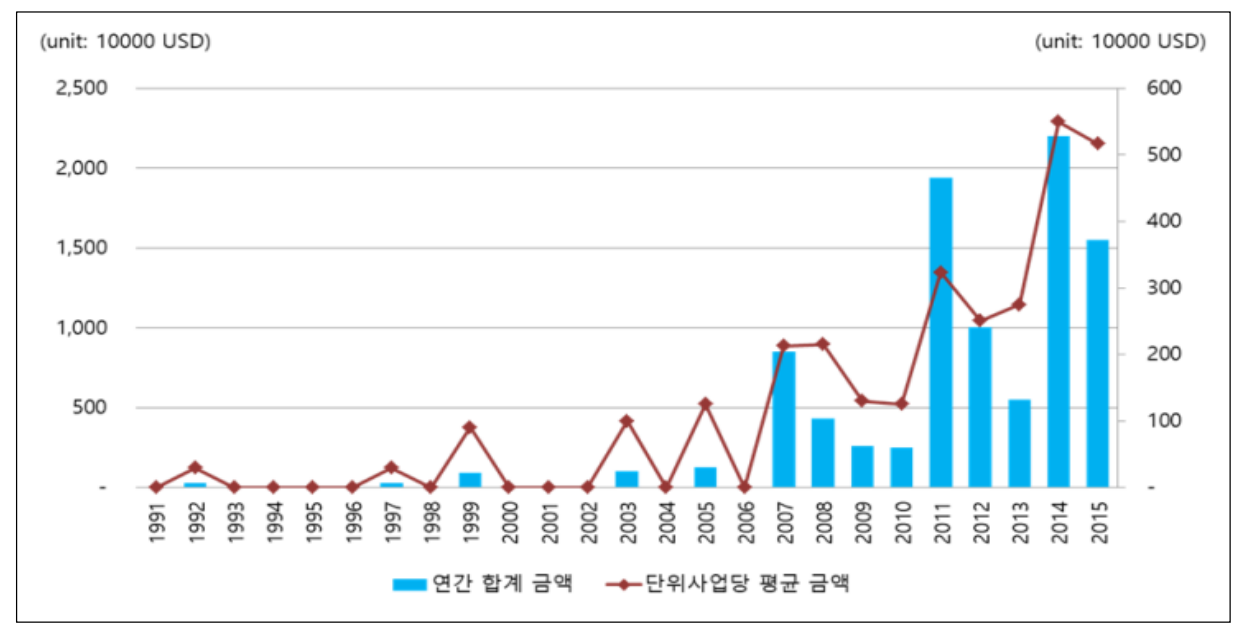

출처: KOICA 통계조회서비스 http://stat.koica.go.kr (접속일: 2017.11.28.), KOICA 내부자료 참고

개발도상국 도시문제 해결을 위한 인프라 분야까지 확대하면, 도시 및 국토개발, 산업에너지, 교통 인프라에 해당하는 사업이 포함 가능하며, 지난 3년간 약 2,000억 원, 연간 KOICA 전체 사업비의 $10 \%$ 내외를 개발도상국의 도시문제 해결을 위해 지원한 것으로 나타난다(<표 $7>$ 참고).

도시 및 국토개발 관련 분야의 사업은 지역개발 및 신도시 마스터플랜 수립과 타당성 조사, 지도제작, 토지등록 및 정보관리시스템 구축사업 등이 대표적이다.

〈표 7〉 KOICA 도시개발 및 인프라 분야 지원 현황 (2014-2016)

\begin{tabular}{|c|c|c|c|c|}
\hline 구분 & 세부사업 & \multicolumn{3}{|c|}{ 분야별 지원금액 } \\
\hline $\begin{array}{l}\text { 도시 및 } \\
\text { 국토개발 }\end{array}$ & $\begin{array}{l}\text { ○ 지역개발 및 신도시 마스터플랜, 타당성 } \\
\text { 조사, 토지등록 및 관리체계 등 }\end{array}$ & \multicolumn{3}{|c|}{$\begin{array}{ccc}\text { - 산업에너지 }=\text { 교통 } & \text { - 도시 및 국토개날 } & \text { (단위: 역원) } \\
731 & 674\end{array}$} \\
\hline $\begin{array}{l}\text { 교통 } \\
\text { 인프라 }\end{array}$ & $\begin{array}{l}\text { ○ 고속도로, 도시 메트로, 철도, 공항, 여객 } \\
\text { 터미널 등 }\end{array}$ & $\frac{538}{114}$ & & \multirow[b]{2}{*}{504} \\
\hline $\begin{array}{c}\text { 산업 } \\
\text { 에너지 }\end{array}$ & $\begin{array}{l}\text { ○ 태양광발전소, 수력발전소 등 재생에너 } \\
\text { 지 사업, ICT 사업, 수자원 개발 및 관리, }\end{array}$ & 381 & & \\
\hline & 상하수도 건설 등 & 2014 & 2015 & 2016(예정) \\
\hline
\end{tabular}

출처 : KOICA 내부자료

$\mathrm{KOICA}$ 에서 추진된 기존 도시개발 분야 사업은 대부분 개발사업(신도시, 산업단지 등)을 위한 마스터플랜 수립이나 타당성 조사에 집중되어 왔다. (<표 8> 참고) 그러나 대부분 장기적 인 개발 방향에 대한 청사진을 제시하는 데 그치고 실제 개발사례로 확대 추진된 사례는 아직 
없는 것으로 나타나고 있다. $\mathrm{KOICA}$ 내부적으로도 이러한 이유에 대해 현지의 경제, 사회적 여건에 대한 면밀한 분석과 대안 제시보다는, 특수한 법적, 제도적 기반 및 급격한 경제성장률을 바탕으로 추진되어온, 협의의 개념에서의 도시계획에 집중하여 사업을 형성하고 추진했다는 것을 가장 큰 원인으로 진단하고 있다(방설아.신유승, 2015).

$\mathrm{KOICA}$ 에서 추진한 도시개발 분야 사업 중 후속 사업으로 연계 추진된 도시 마스터플랜 사례는 3 장에서 소개하였다.

〈표 8〉 KOICA 도시개발 분야 지원사업 리스트(1991 2015)

\begin{tabular}{|c|c|c|c|c|}
\hline 국가 & 사업유형 & 사업명 & 사업기간 & $\begin{array}{c}\text { 사업비 } \\
\text { (만불) }\end{array}$ \\
\hline \multirow{3}{*}{$\begin{array}{c}\text { 인도 } \\
\text { 네시아 }\end{array}$} & 프로젝트 & 인도네시아 자바 북부해안 공간정보시스템 구축사업 & 2013 2015 & 350 \\
\hline & 개발컨설팅 & 인도네시아 중부 자바 섬유공단조성 타당성 조사사업 & $2011 \sim 2014$ & 480 \\
\hline & 개발컨설팅 & 인도네시아 자카르타 수도권해안종합개발 컨설팅사업 & 2014 2017 & 950 \\
\hline \multirow{2}{*}{ 라오스 } & 개발컨설팅 & 라오스 지도제작 인력양성 및 지형도 제작사업 & $2014 \sim 2017$ & 350 \\
\hline & 개발컨설팅 & 라오스 사반세노 특별경제구역 지도구축사업 & 2008 2009 & 180 \\
\hline \multirow{2}{*}{ 몽골 } & 개발컨설팅 & 몽골 울란바타르시 토지정보통합시스템 구축사업 & $2011 \sim 2013$ & 270 \\
\hline & 개발컨설팅 & 몽골 동북아 종합개발계획 수립조사 & $1997 \sim 1998$ & 29 \\
\hline 미얀마 & 개발컨설팅 & $\begin{array}{l}\text { 미얀마 한따와디 신공항 인근 및 양곤 남서부 지역개발 마스터 } \\
\text { 플랜 수립사업 }\end{array}$ & 2015 2017 & 500 \\
\hline 네팔 & 개발컨설팅 & 네팔 룸비니지역 개발 마스터플랜 수립사업 & 2012 2014 & 200 \\
\hline \multirow{2}{*}{ 필리핀 } & 개발컨설팅 & 필리핀 동부 비사야스 지역 공단조성사업 & $1992 \sim 1993$ & 29 \\
\hline & 개발컨설팅 & 필리핀 농공복합단지 타당성 조사사업 & 2009 2010 & 110 \\
\hline \multirow{7}{*}{ 베트남 } & 프로젝트 & 베트남 토지정보 종합관리 시스템 개발지원사업 & 2012 2015 & 350 \\
\hline & 개발컨설팅 & 베트남 하노이 신도시 개발 타당성 조사 & 1999 2001 & 91 \\
\hline & 개발컨설팅 & 베트남 하이퐁시 신도시 개발 세부 마스터플랜 수립 & $2007 \sim 2010$ & 400 \\
\hline & 개발컨설팅 & 베트남 후에시 마스터플랜 개선 및 수립사업 & 2011 2014 & 350 \\
\hline & 개발컨설팅 & 베트남 국가녹색성장 마스터플랜 수립사업 & 2013 2016 & 200 \\
\hline & 개발컨설팅 & 베트남 후에시 향강 연안개발 상세계획 수립 및 시범사업 상세설계 & 2014 2015 & 600 \\
\hline & 개발컨설팅 & 베트남 그린시티 도시계획 의사결정시스템 구축사업 & 2015 2017 & 650 \\
\hline 알제리 & 개발컨설팅 & 알제리 과학기술신도시 개발 마스터플랜 & 2003 2004 & 100 \\
\hline \multirow{2}{*}{ 가나 } & 개발컨설팅 & 가나 아한타웨스트 신도시개발계획 수립사업 & 2009 2010 & 150 \\
\hline & 개발컨설팅 & 가나 아한타웨스트 신도시 개발계획 수립 2차사업 & 2010 2011 & 100 \\
\hline 케냐 & 개발컨설팅 & 케냐 라무항 및 인근 지역 지도제작사업 & $2011 \sim 2013$ & 280 \\
\hline
\end{tabular}




\begin{tabular}{|c|c|c|c|c|}
\hline 국가 & 사업유형 & 사업명 & 사업기간 & $\begin{array}{l}\text { 사업비 } \\
\text { (만불) }\end{array}$ \\
\hline 모로코 & 개발컨설팅 & 모로코 종합토지등록 방안 수립 및 시범사업 & 2007 2008 & 100 \\
\hline 튀니지 & 개발컨설팅 & 튀니지 갑사 테크노파크 타당성 조사사업 & 2012 2013 & 53 \\
\hline 콜롬비아 & 개발컨설팅 & 콜롬비아 깔리시 주택단지 마스터플랜 수립사업 & 2014 2016 & 300 \\
\hline 온두라스 & 개발컨설팅 & 온두라스 특별개발지구 타당성 조사사업 & 2012 2015 & 400 \\
\hline 자메이카 & 프로젝트 & 자메이카 지적도제작 및 토지등록사업 & 2011 2014 & 210 \\
\hline $\begin{array}{l}\text { 아제르 } \\
\text { 바이잔 }\end{array}$ & 프로젝트 & 아제르바이잔 경제특별구역 및 산업단지 개발사업 & 2008 2013 & 250 \\
\hline $\begin{array}{c}\text { 키르기즈 } \\
\text { 공화국 }\end{array}$ & 프로젝트 & 키르기즈공화국 토지정보 종합관리시스템 구축사업 & 2015 2017 & 400 \\
\hline 우즈벡 & 프로젝트 & 우즈벡 국가지리정보시스템 구축사업 & 2005 2006 & 125 \\
\hline 캄보디아 & 프로젝트 & 캄보디아 국토관리 기반조성을 위한 국가측량기준점 설치사업 & 2007 2009 & 250 \\
\hline 카자흐스탄 & 개발컨설팅 & 카자흐스탄 관광산업진흥 마스터플랜 수립사업 & 2007 2008 & 100 \\
\hline $\begin{array}{l}\text { 투르크 } \\
\text { 메니스탄 }\end{array}$ & 개발컨설팅 & 투르크메니스탄 토지등록 및 지적제도 현대화사업 & 2010 2012 & 150 \\
\hline 남수단 & 개발컨설팅 & 남수단 신수도 건설 마스터플랜 수립사업 & 2011 2015 & 350 \\
\hline
\end{tabular}

출처: KOICA 통계조회서비스 (htp://stat.koica.go.kr) (접속일: 2017.11.28), KOICA 내부자료 참고 


\section{KOICA 도시 마스터플랜 사업의 성과와 후속사업 연계 사례}

이 장에서는 한국의 무상원조사업으로 추진된 도시개발 분야 $\mathrm{ODA}$ 사업으로서 베트남 후에

시 마스터플랜 사업을 소개하고 주요 시사점을 논의하고자 한다.

$\mathrm{KOICA}$ 의 후에시 마스터플랜 사업은 베트남의 대표적인 역사문화도시이자 관광도시인 후에 시(Hue City)를 대상으로 베트남 법률(건설법, 도시계획법) 상의 법정계획인 도시 마스터플랜 을 수립하고 한국의 원조사업으로서는 최초로 협력대상국 중앙정부의 승인을 받은 사례이다. 또한, 개발도상국의 주요 공동과제인 도시개발과 보존의 조화, 역사문화유산 관리에 대한 한국 의 경험을 공유하고, 후속연계사업으로 확대 추진된 사례로서 주요 성과와 시사점을 가진다.

섹 터

포

커

$\underline{\Lambda}$

제표장

\section{1. 베트남 후에시 마스터플랜 사업 : KOICA}

\section{1) 베트남 공간계획 관련 법률 및 정책}

후에시 마스터플랜을 구체적으로 설명하 기 이전에, 베트남의 공간계획 및 도시개발 관리에 대한 법적 체계와 현황을 우선 소개 하고자 한다. 도시개발 분야의 컨설팅 사업 을 기획하고 실행하기 위해서는 해당 국가 의 공간계획 관련 법률체계와 정책에 대한 이해가 필수적이다.

베트남 행정구역 체계는 58개 성(province, 이하 성)과 5 개의 중앙도시(centrally-run city)로 구성되어 있다(<그림 3> 참고). 후에 시는 58 개 성 중 하나인 투아티엔 후에성 (Thua Thien Hue Province, 이하 후에성) 의 성도(provincial city)이며, 하노이, 호치 민, 하이퐁, 깐토, 다낭에 이어 6 번째 중앙도 시로 승격이 결정(Decision $48 / \mathrm{TW}-\mathrm{KL}$ 2009)된 중부지역의 거점도시이다.
〈그림 3〉 베트남 행정구역도

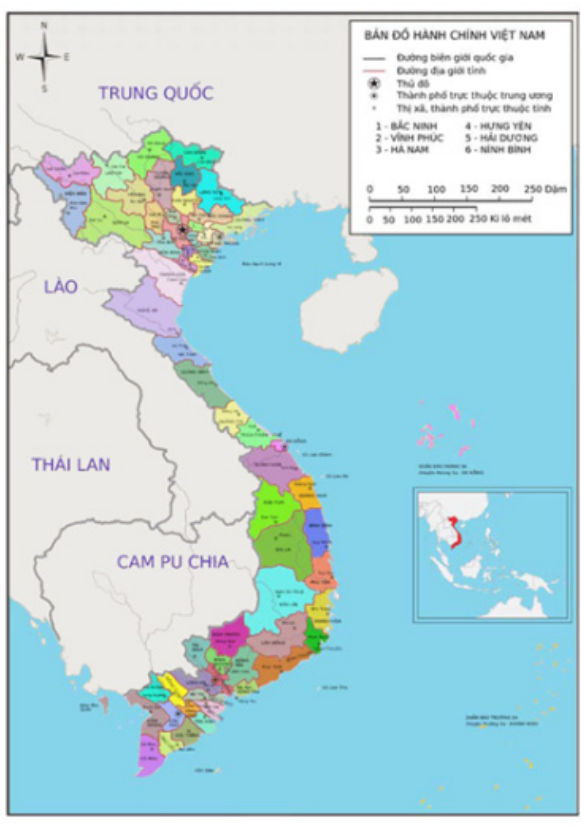

출처: (https://vi.wikipedia.org)

(접속일: 2017.12.05.) 
베트남에는 한국의 국토종합계획에 해당되는 전국 차원의 공간개발계획은 없으나, 정부의 정책 방향을 포함하는 사회경제개발계획(socio-economic development plan)과 부문별 계획에 서 도시개발전략이 제시되고, 이에 따라 공간계획으로서 지역계획(regional plan)이 수립된다 <그 림 4> 참고). 베트남 정부는 2009년 베트남 도시 시스템 개발계획 2025 비전 2050(Orientation for Vietnam's Urban System Development to 2025 vision 2050, Decision No.445/ QD-TTg, 2009)을 수립하고, 2012년 국가 도시개발 프로그램 2020(National Urban Development Program 2020, Decision No.1659/QD-TTg, 2012)을 승인하였다.

〈그림 4〉베트남 공간계획(Spatial Plan) 체계

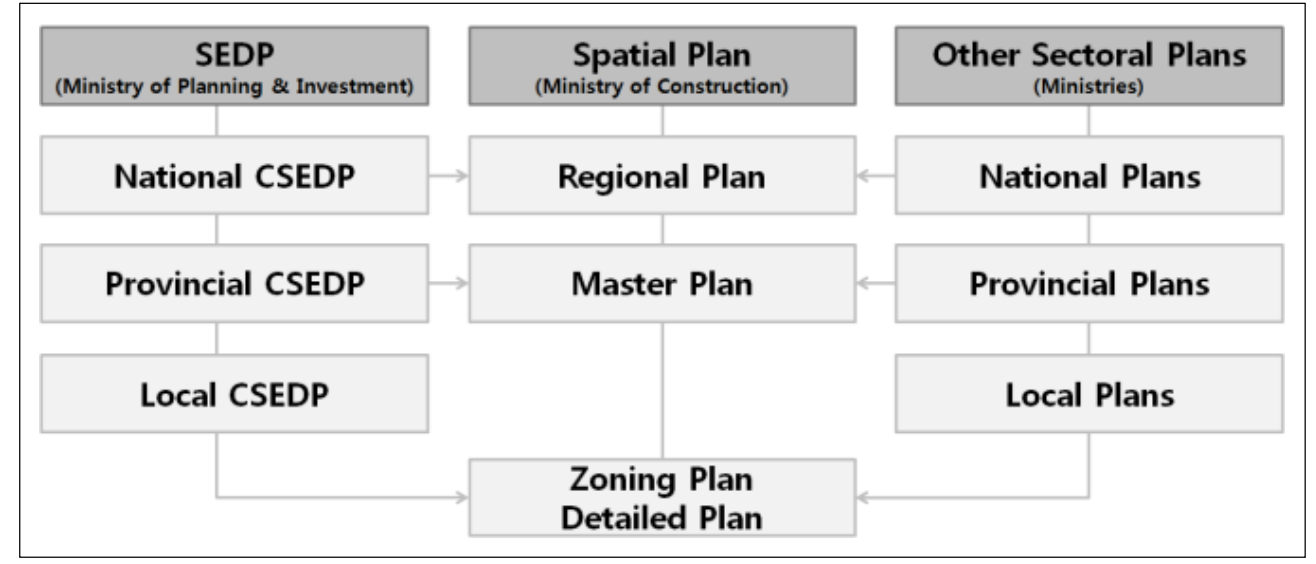

* 주: CSEDP: Comprehensive Social and Economic Development Planning

출처: Nguyen Trung Dzung, 제 3회 아시아법제교류 전문가회의 (2015.11.04 개최) 발표자료 참고 저자 작성

지역계획은 개별 성(province) 혹은 두 개 이상의 성에 걸쳐서 수립된다. 지역계획의 하위계 획으로 도시계획(urban planning)에 해당되는 도시 마스터플랜(general master plan), 지역지 구계획(zoning plan), 상세계획(detailed plan)이 있는데, 이는 내용의 구체성과 제도적 구속력 등의 차이로 구분된다. 도시 마스터플랜은 중앙도시(centrally-run city), 성도(Provincial city), 타운(town) 등을 대상으로, 지역지구계획은 도시 내 특정 지역과 타운, 신 도심지 등을 대상으로 수립한다. 상세계획은 도시개발 및 관리를 위해 필요한 지역이나 건설투자가 요청되는 지역을 대상으로 수립한다(<그림 5 6> 참고). 
〈그림 5〉베트남 건설계획 체계 (2014년 건설법 및 2009년 도시계획법 기준)

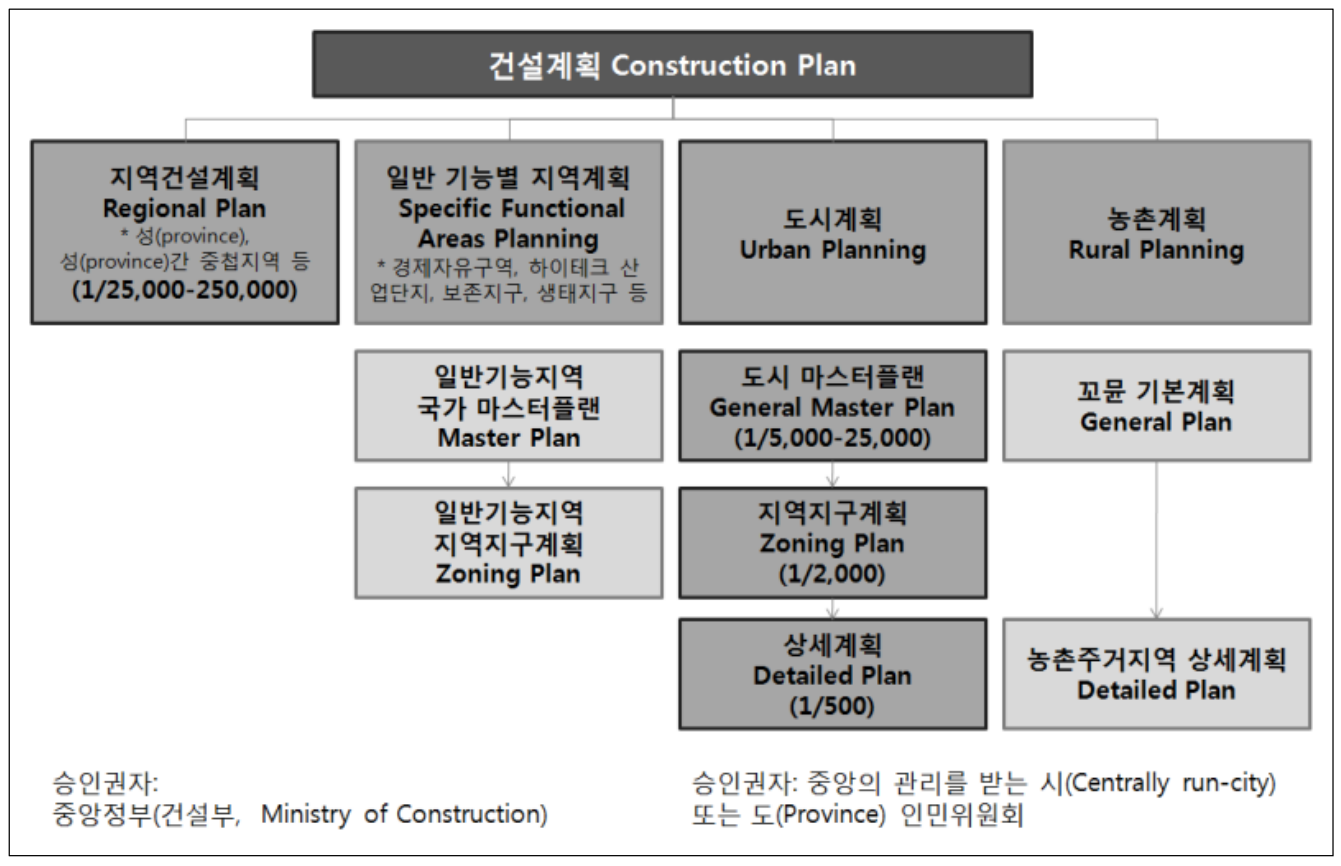

출처: Nguyen Trung Dzung, 제 3회 아시아법제교류 전문가회의 (2015.11.04 개최) 발표자료 참고 저자 작성

〈그림 6〉베트남 도시계획 및 개발관리의 법적 체계

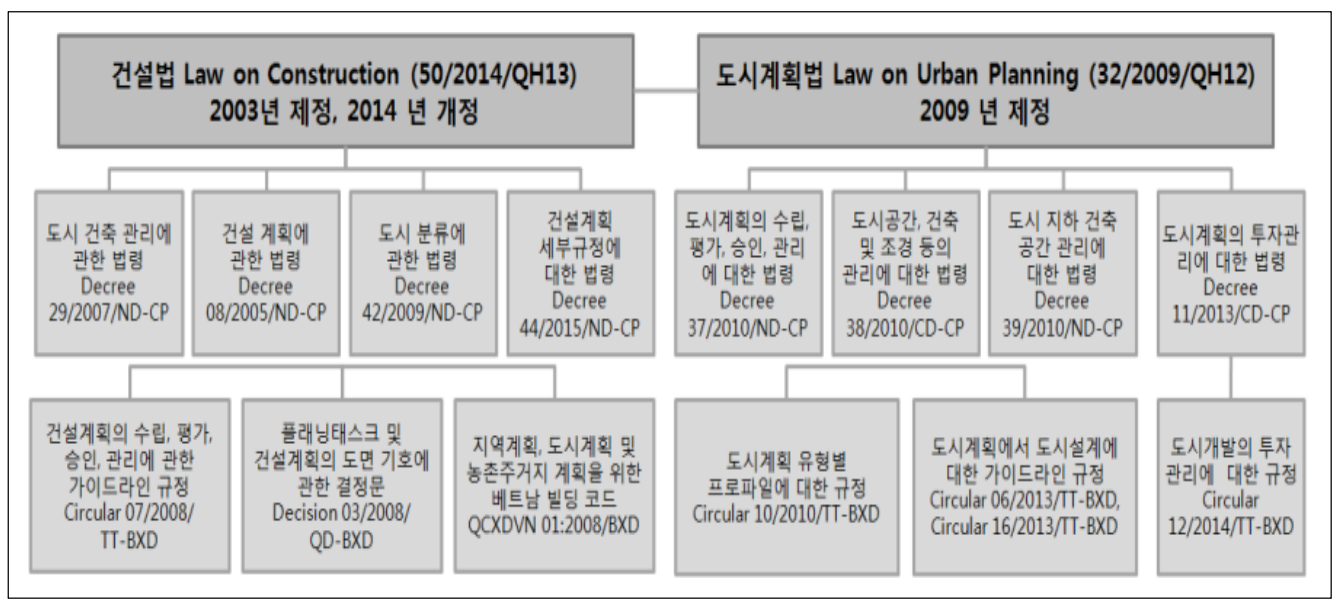

출처: Nguyen Trung Dzung, 제 3회 아시아법제교류 전문가회의 (2015.11.04 개최) 발표자료 참고 저자 작성 
〈그림 7〉 베트남 도시개발 관리 프로세스

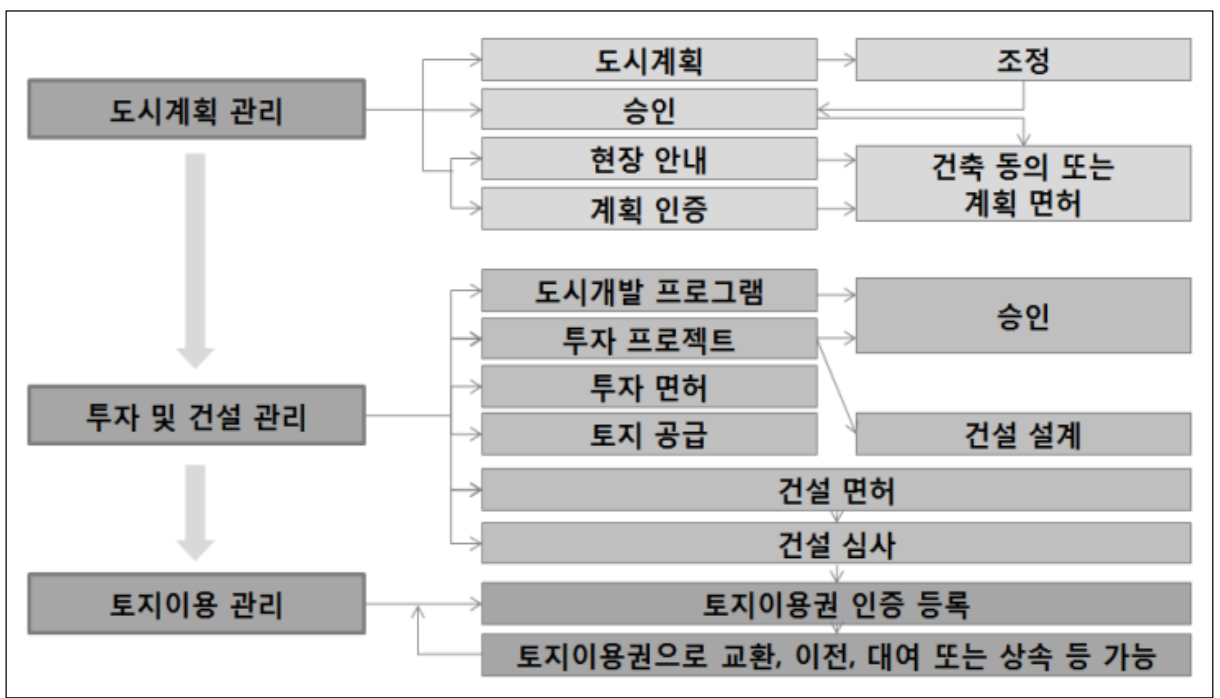

출처: Nguyen Trung Dzung, 제 3회 아시아법제교류 전문가회의 (2015.11.04 개최) 발표자료 참고 저자 작성

\section{2) 사업개요 및 추진배경}

KOICA 사업으로 추진된 후에시 마스터플랜 사업(사업명: 베트남 후에시 마스터플랜 개선 및 수립사업)은 베트남 건설계획 체계에서 성도(provincial city)를 대상으로 하는 도시 마스터 플랜을 수립하기 위한 개발컨설팅 사업이다. 베트남 법률상의 도시 마스터플랜은 20년 단위의 장기계획으로서 도시 비전, 계획지표, 도시 공간구상, 토지이용계획, 역사문화 및 관광, 기술 인프라, 경제 분야 등을 포함하는 총체적 계획(comprehensive plan)의 성격을 지니며, 공적 실행력을 갖춘 법정계획에 해당된다.

후에시는 베트남 중앙도시로의 승격이 결정된 중부지역의 거점도시이다. 또한, 베트남의 마 지막 왕조인 응우옌 왕조(Nguyen Dynasty, 1802 1945)의 고도(古都)로서 국제연합교육과 학문화기구(United Nations Educational Scientific and Cultural Organization, 이하 UNESCO) 세계문화유산으로 지정된 역사문화도시(UNESCO World Heritage, 1993)이자, 베트남 유일의 페스티벌 시티로 지정된 도시(festival city, Decision 143/QD-TTg, 2007)이 다. 1999년 후에시 자체적으로 도시 마스터플랜을 수립한 이후, 10년 이상 빠르게 변화한 도시 여건과 현황을 반영하지 못해 도시 관리에 어려움을 겪고 있었다. 이에 따라 후에시와 베트남 정부는 한국의 양자 간 무상원조사업으로 후에시 마스터플랜 수립사업을 요청하였으며, $\mathrm{KOICA}$ 는 후에시의 지속가능한 성장 및 발전을 위해 지원사업을 시행하였다. 
사업 기간은 약 28 개월이며, 사업내용은 후에시 마스터플랜 수립, 현지 워크솝 및 사업설명회 개최, 국내 연수초청, 기자재 지원으로 구성된다. 계획범위는 향후 중앙도시로의 승격을 고려하 여 현재 후에시 $\left(70.99 \mathrm{~km}^{2}\right)$ 를 포함하는 도시 확장구역 범위 $\left(\right.$ 약 $\left.348 \mathrm{~km}^{2}\right)$ 를 대상으로 수립되었다.

효율적인 사업추진을 위해 한국 전문가로서 마스터플랜 수립 컨설팅 수행기관과 $\mathrm{PMC}$ (Project Management Consultancy) 수행기관을 별도로 선정하여 사업을 수행5)하였고, 베 트남 측에서는 후에성과 후에시의 각 부서별 공무원으로 구성된 PMU(Project Management Unit)를 조직하여 한국 전문가들과 상호 협력체계를 구축하여 사업을 수행하였다.

후에시 마스터플랜 사업은 2011년 8월 착수하여 현지 워크솝 및 보고회, 하노이 사업설명회 및 베트남 건설부 심의회를 거쳐 약 28개월간 프로젝트가 추진되었고, 2014년 5월 베트남 중앙정부 승인(Decision 649/QD-TTg)을 받음으로써 베트남 내에서도 사업이 종결되었다.

〈표 9〉 베트남 투아티엔 후에성 후에시 개요

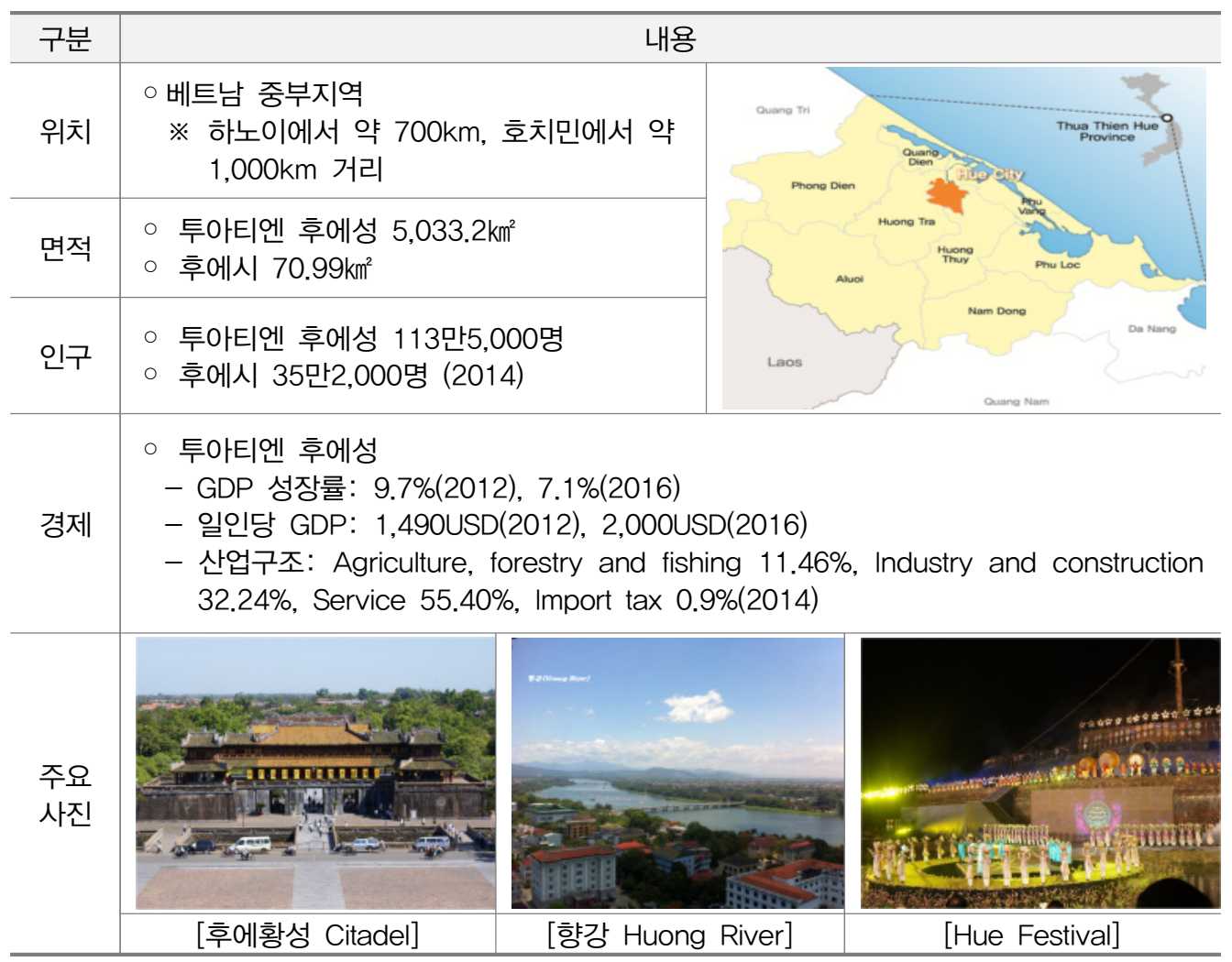

출처: 한아도시연구소건축사사무소 (2015)

5) 마스터플랜 수립 컨설팅은 (주한아도시연구소건축사사무소.(주도화엔지니어링 컨소시엄이 수행하고, $\mathrm{PMC}$ 는 한국토지 주택공사(LH)가 수행하였다. 
본 사업은 마스터플랜 수립 과정에서 후속 사업의 발굴 및 협의가 동시에 진행되었는데, 이는 $\mathrm{ODA}$ 사업의 일반적인 사업화 절차와 소요시간(양자 간 약 2년, 다자간 약 3-5년 소요)을 고려 시, 사업 초반 $\mathrm{ODA}$ 수행기관 및 협력대상국 의사결정 주체와 후속 사업에 대한 방향이 조기 설정되어야 실행 가능성이 높아지기 때문이다.

〈표 10〉베트남 후에시 마스터플랜 개선 및 수립사업 개요

\begin{tabular}{|c|c|}
\hline 구분 & 내용 \\
\hline 사업명 & $\begin{array}{l}\text { 베트남 후에시 마스터플랜 개선 및 수립사업 } \\
\text { (The Modification of Hue City's Master Plan) }\end{array}$ \\
\hline 사업 기간 & ○ $\quad 2011.8 \sim 2013.12$ \\
\hline 대상지 & $\begin{array}{l}\text { 베트남 투아티엔후에성 후에시 } \\
\text { (Hue City, Thua Thien Hue Province, Vietnam) }\end{array}$ \\
\hline 수행기관 & $\begin{array}{l}\text { 우한아도시연구소건축사사무소, (주)도화엔지니어링 컨소시엄 } \\
\text { ※ 협력기관: 삼정KPMG, 한얼문화유산연구소, 순천향대학교 }\end{array}$ \\
\hline 사업내용 & $\begin{array}{l}\circ \text { 후에시 마스터플랜 } 2030 \text { 비전 } 2050 \text { 수립 } \\
\circ \text { 현지 워크숍 및 사업설명회 개최 } \\
\circ \text { 한국 연수초청, 기자재 지원 등 }\end{array}$ \\
\hline $\begin{array}{l}\text { 주요 추진 } \\
\text { 경위 }\end{array}$ & $\begin{array}{l}\circ \text { 2010년 프로젝트 형성 } \\
\circ \text { 2011년 프로젝트 착수(2011.8) } \\
\circ \text { 2012년 후에시 마스터플랜 수립 } \\
\circ \text { 2013년 하노이 사업설명회 개최(2013.11) } \\
\text { 베트남 중앙정부 건설부 심의회 개최(2013.11) } \\
\text { ○ 2014년 후에시 마스터플랜 수상실 승인(2014.5) }\end{array}$ \\
\hline
\end{tabular}

출처: 한국국제협력단 (2014) 참고 저자 작성

\section{3) 도시 마스터플랜 주요 내용}

후에시 마스터플랜 수립 시 고려된 주요 계획적 이슈는 크게 세 가지이다. 급속한 도시화가 예상되는 개발도상국의 역사문화도시로서 도시개발과 역사문화유산 보존의 조화, 우수한 자연 환경의 보존과 활용, 상습적인 홍수범람 문제의 기술적 해결방안이 이에 해당된다.

첫 번째는 도시개발과 역사문화자원 보존의 조화에 대한 사항이다. 후에시는 도시 전체에 $\mathrm{UNESCO}$ 에서 지정한 풍부한 역사문화유산이 분포하고 있으며, 특히 후에 황성(Citadel)은 응우옌 왕조의 황궁이 위치한 구시가지로서 10 만 명 이상의 인구가 내부에 거주하고 있어 역사문화자원을 보존함과 동시에 현재 거주민의 삶에 대한 계획적 고려가 필요하였다. 또한, 티엔무사원, 황릉 등 역사문화유산이 다수 분포한 향강(Huong River)변 도시개발 수요증가가 
예상되나, 도시 내 문화유산 보존과 주변 지역 관리에 대한 구체적 해결방안이 마련되지 않아 지방정부 차원에서 도시를 관리함에 있어 어려움이 있었다. 따라서 후에시 마스터플랜에서는 증가하는 도시개발 수요를 신규 외곽지역으로 유도하고, 역사문화유산과 그 주변 지역에 대해서 는 한국의 문화유산 보존에 대한 제도와 경험을 토대로 베트남 현지에 적용 가능한 관리방안을 검토하여 제시하고자 하였다.

두 번째는 우수한 자연환경의 보존과 활용에 대한 사항이다. 후에시가 위치한 베트남 중부지 역은 자연환경이 우수하고 해양, 라군, 산림 등 다양한 생태계와 생물군을 보유하고 있어 $\mathrm{ADB}$ 의 생물다양성회랑(biodiversity corridor)으로 지정된 지역이다. 국제적 수준의 생태적 가치 를 갖는 도시자원을 토대로 미래 도시 성장 동력을 확보할 수 있는 산업과 발전 방항을 설정하고 단계별 개발전략을 제시하였다.

마지막은 집중호우에 따른 상습적인 홍수범람 문제로서, 베트남 중부지역은 매년 9월 12월 우기 기간 동안 연간 강우량의 약 $70 \%$ 에 이르는 집중호우가 발생하여 도시지역 및 농경지가 주기적으로 침수되는 기후적 특성을 보인다. 특히 후에시의 경우 하천 하류 지역에 위치하여 기후변화 및 집중호우에 취약한 입지특성을 지니고 있어 이에 대한 기술적 해결방안이 주요 계획이슈로 검토되었다.

후에시의 미래 도시 비전은 인도차이나반도 내 고도(古都) 관광 삼각망(후에-시엠립-루앙프 라방)의 핵심도시이자 베트남 국가발전의 3대 전략적 거점(하노이-행정수도, 호치민-경제수도, 후에-문화수도)으로서, 이를 구체화하기 위한 발전목표는 인도차이나반도 최고의 문화창조도 시, 베트남 최첨단 지식산업 거점도시, 아세안의 대표적 환경모범도시로 설정되었다.

후에시 공간구조구상은 생태적 건강성과 도시 성장의 지속가능성 확보, 대중교통 중심의 집약적 도시 정비와 개발, 기반시설의 효율적 공급이라는 기본원칙 하에 수립되었다. 특히 역사 문화자원이 다수 분포하여 보존이 필요한 지역, 기후변화에 취약하고 생태적 환경이 우수한 지역은 보존하는 반면, 증가하는 도시개발 수요에 대응하는 신규 개발지역은 역사문화자원에 영향을 주지 않는 외곽지역으로 유도하고 대중교통계획과 연계하여 집약적으로 개발하는 도시 공간구조를 제안하였다. 


\section{〈그림 8〉 후에시 마스터플랜 상의 도시 비전과 발전전략}

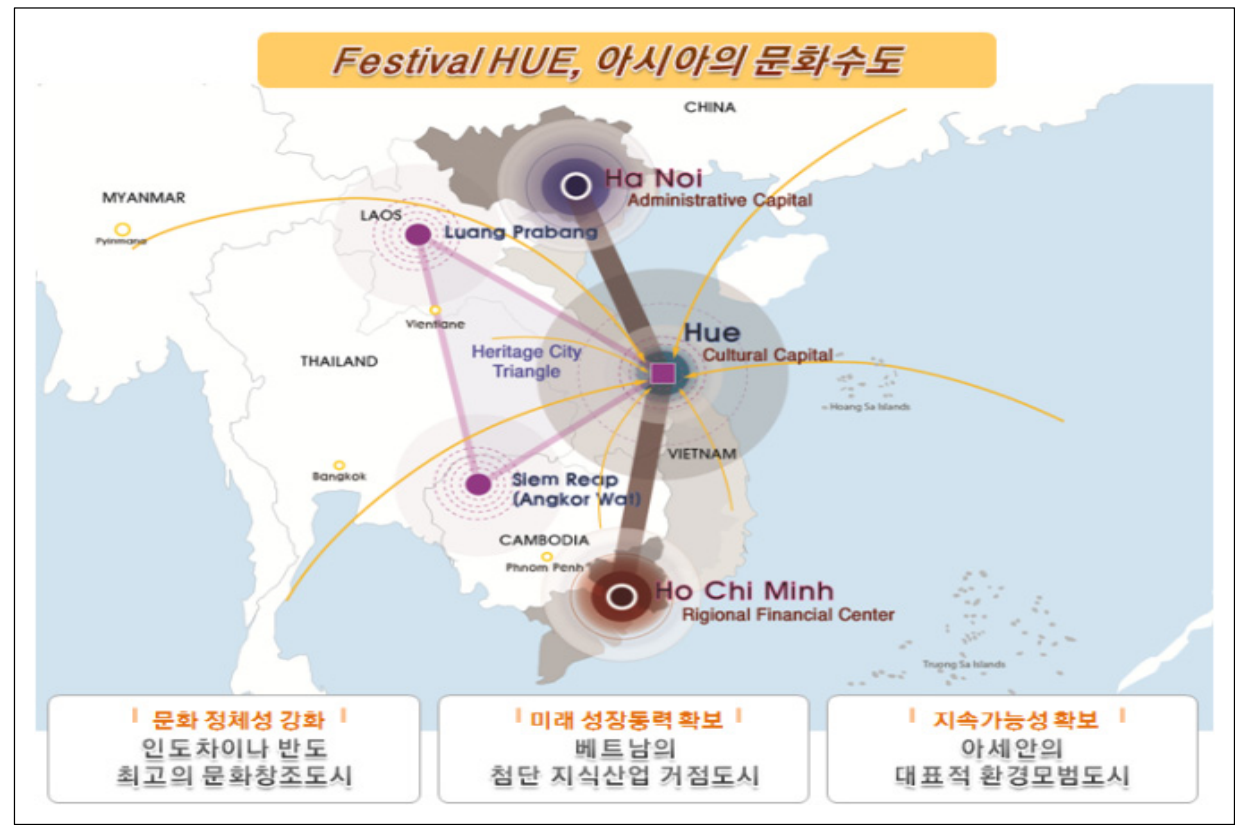

출처: 한국국제협력단 (2013)

후에시 마스터플랜 상에는 베트남 도시계획 관련 법률에서 요구하는 부문별 계획(기능구역 계획, 사회 인프라 체계, 건축경관 관리방안, 역사문화 보존방안, 관광 활성화방안, 기술인프라 개발 방향, 도시설계방안, 실행계획 등)이 포함되어 있다.

이 중 역사문화도시인 후에시의 주요 계획이슈로서 한국 전문가 측에서 중요하게 검토하여 수립한 부문별 계획은 역사문화 보존방안이다. 후에시는 UNESCO 권고사항과 베트남 문화재 보호법을 통해 도시 내 역사문화자원이 관리되고 있으나, 보존관리에 대한 큰 방향성만 제시되 어 있고 보호구역 내 건설행위 등 구체적 실행방안이 부족하다는 한계점이 있었다. 이에 따라 후에시 마스터플랜에서는 베트남 역사문화보존 관련 제도를 토대로 한국의 역사문화보존 관련 제도6) 사례를 검토하여 적용 가능한 시사점을 도출하고, 베트남 현지 전문가 및 관련 기관(Hue Monument Conservation Center, $\mathrm{HMCC}$ ), 공무원과의 협의 과정을 통해 역사문화자원 보 호구역에 대한 4단계 조닝 개념과 보호구역 계획안 등 베트남 관련 제도에 적용 가능한 관리방 안을 제안하였다.

6) 문화재 주변 현상변경허가처리기준, 고도(古都)보존에 관한 특별법 


\section{〈그림 9〉 후에시 마스터플랜 상의 토지이용계획, 역사문화자원 보호구역 조닝}

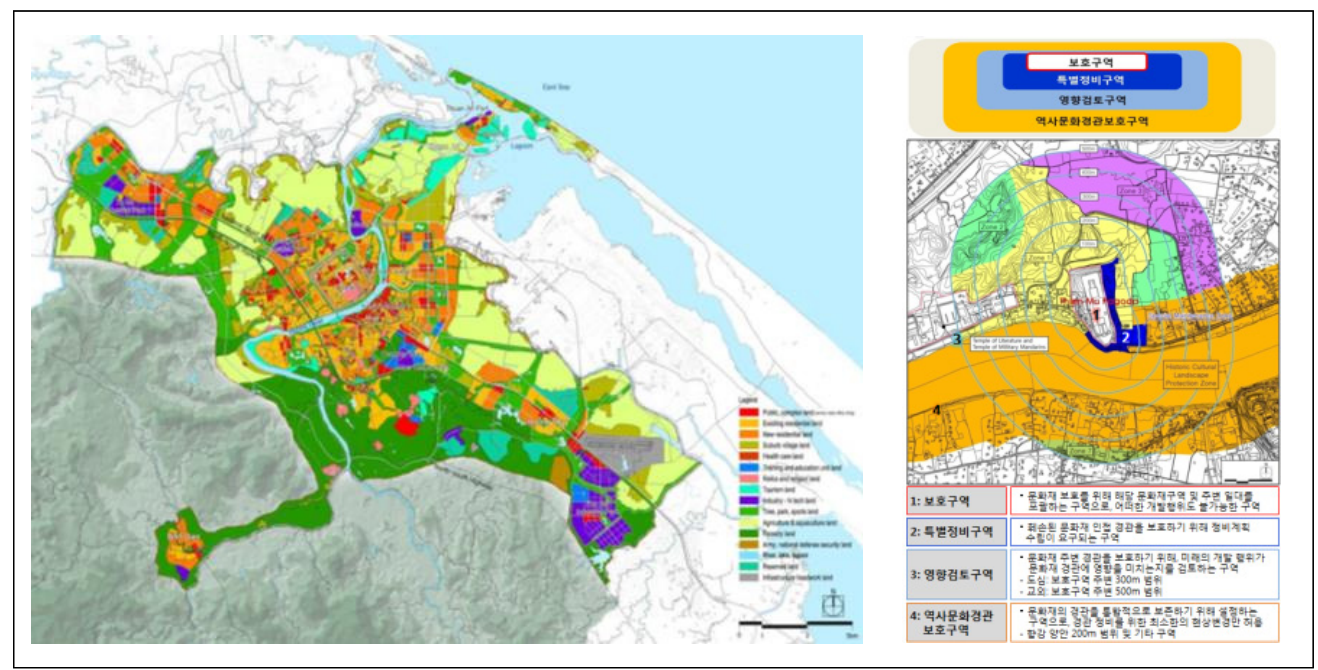

출처: 한국국제협력단 (2013)

\section{4) 주요 성과 및 시사점}

후에시 마스터플랜 사업은 도시개발 분야 ODA 사업으로서 다음의 주요 성과와 시사점을 가진다.

첫 번째로, 후에시 마스터플랜에 대한 베트남 수상실 승인을 받음으로써 한국 ODA 사업으로 서는 최초로 베트남 법률에 근거한 행정절차 상의 모든 승인과정을 거친 법정 도시계획 사례가 되었다.

두 번째로, 후에시 마스터플랜 사업은 본 사업인 도시 마스터플랜 수립에 그치지 않고 후속 사업을 발굴하고 연계시킴으로써 마스터플랜의 실행력을 담보하고 사업의 연속성을 확보한 사례이다. 개발도상국에 대한 도시 마스터플랜을 한국 정부와 기업에서 수립할 경우, 마스터플 랜 이후 부문별 세부계획과 개별 건설사업 발주단계에서 국내 기업의 진출 확대를 기대할 수 있다. 마스터플랜 사업 수행을 통해 협력대상국 및 도시의 정치, 경제, 사회, 인프라 현황 등에 대한 종합적인 개발조사 시행과 자료 구축이 가능하며, 현지 네트워크를 구축할 수 있기 때문이다.

후에시 마스터플랜 사업의 경우, 사업 초기 단계에 도시 비전 달성을 위한 전략사업을 제안하 였으며, 실행계획 수립 단계에서는 향후 도시개발 및 정비를 위해 우선 투자되어야 하는 공공인 프라 세부사업을 후속 사업으로 제안하고 협력대상국, $\mathrm{KOICA}, \mathrm{ADB}$ 등과 협의함으로써, 한국 $\mathrm{ODA}$ 후속 사업(향강 프로젝트)과 $\mathrm{ADB}$ 연계사업(그린시티 프로그램)으로 확대되었다. 
〈그림 10〉 도시 마스터플랜 및 후속사업 연계 예시도

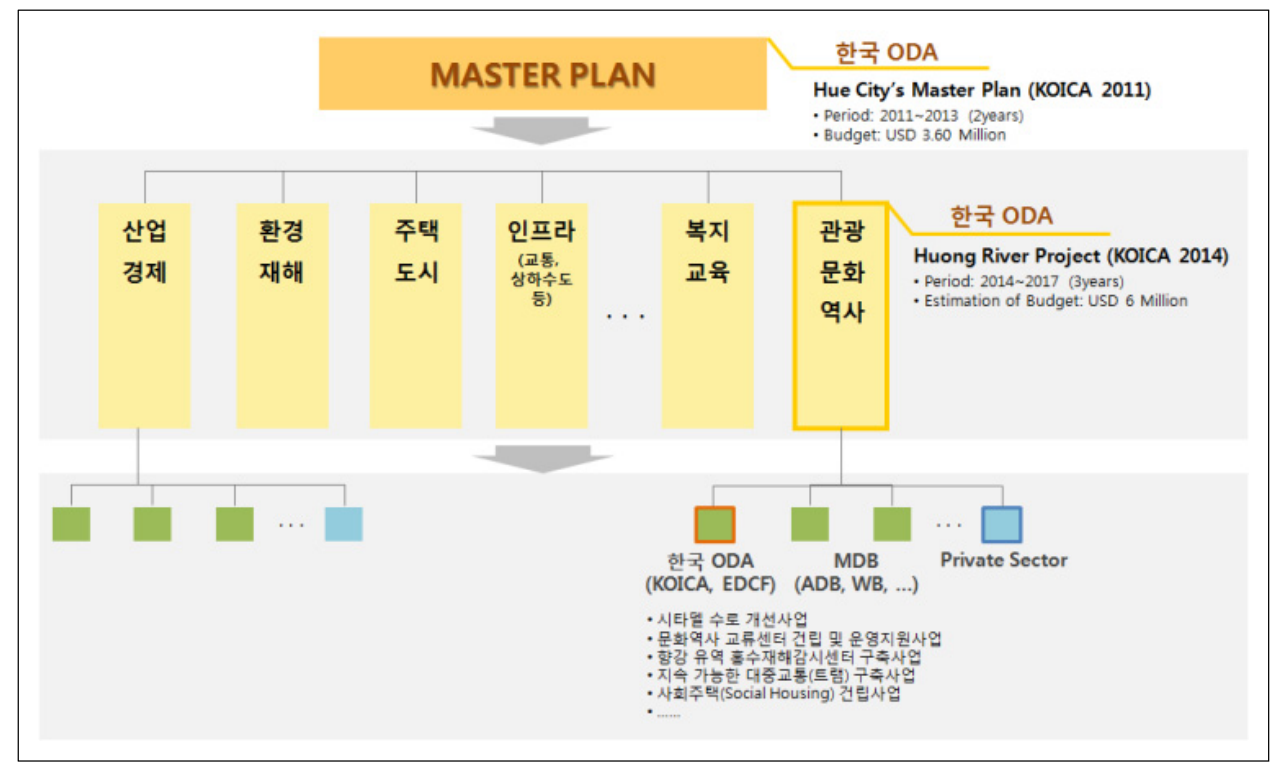

출처: 저자 작성

\section{2. 후에시 마스터플랜 연계사업 : KOICA, ADB}

\section{1) $\mathrm{KOICA}$ 후속 사업 : 향강 연안 상세계획 및 시범사업 상세설계}

향강 연안개발 상세계획 수립 및 시범사업 상세설계 사업은 후에시 마스터플랜 사업의 후속 연계사업으로서, 후에시 향강 연안부에 대한 상세계획을 수립하고 시범사업에 대한 설계 및 시공사업을 포함한다.

사업 기간은 약 3 년이며, 사업내용은 향강 연안부에 대한 상세계획 수립, 시범사업 선정 및 상세설계, 시공지원으로 구성된다.

〈표 11〉 향강 연안 상세계획 및 시범사업 상세설계 사업개요

\begin{tabular}{c|c}
\hline 구분 & 내용 \\
\hline 사업명 & $\begin{array}{c}\circ \text { 베트남 후에시 향강 연안개발 상세계획 수립 및 시범사업 상세설계 (The Detailed } \\
\text { Planning of Huong Riversides and the Detailed Design of Pilot Project) }\end{array}$ \\
\hline 사업 기간 & $\circ 2014.12 ~ 2018.8$ (44개월) \\
\hline 대상지 & $\circ$ 베트남 투아티엔후에성 후에시 향강 양안 약 15km 구간 \\
\hline
\end{tabular}




\begin{tabular}{|c|c|}
\hline 구분 & 내용 \\
\hline 수행기관 & $\begin{array}{l}\text { 을한아도시연구소건축사사무소, (주)도화엔지니어링 컨소시엄 } \\
\text { ※ 협력기관: 서울대학교 산학협력단, } \mathrm{mlnp}\end{array}$ \\
\hline 사업내용 & $\begin{array}{l}\text { ○ 향강 연안 지역 상세계획 수립 } \\
\circ \text { 시범사업 선정 및 상세설계 수립, 시공지원 } \\
\text { ※ 시범사업 시공사업은 KOICA 별도예산으로 추진 } \\
\text { ○ 한국 연수초청, 워크숍 개최, 기자재 지원 등 }\end{array}$ \\
\hline $\begin{array}{l}\text { 주요 추진 } \\
\text { 경위 }\end{array}$ & $\begin{array}{l}\text { ○ 2013년 프로젝트 형성 } \\
\text { ○ 2015년 프로젝트 착수(2015.1) } \\
\text { ○ 2016년 향강 연안 상세계획 수립 } \\
\text { 시범사업 선정 및 상세설계 수립 } \\
\text { ○ 2017년 시범사업 상세설계 후에성 승인(2017.3) } \\
\text { 시범사업 시공사 입찰 공고 및 선정(2017.7 11) } \\
\quad \text { 향강 연안 상세계획 최종보고회 개최(2017.11) } \\
\text { - 2018년 시범사업 완공 및 워크숍 개최 예정(2018.4 8) }\end{array}$ \\
\hline
\end{tabular}

출처: 한국국제협력단 (2017)

후에시 중심부를 관통하는 향강(Huong River)은 후에성과 후에시의 역사적, 미래적 중요한 자원으로서 과거에서 미래를 연결하고 친환경도시로 발전하는데 중요한 역할을 수행하고 있다. $\mathrm{UNESCO}$ 에서도 향강의 가치에 주목하고 향강을 세계문화유산으로 등재할 것을 권장하고 있으며, 후에시 마스터플랜에서도 향강을 주요 도시발전축으로 설정하였다. 그러나 후에시 향강 변은 각종 개발사업으로 경관이 훼손되고 있어 장기적 관점에서 체계적인 관리계획이 필요한 실정이었다. 이에 따라 후에시 마스터플랜 승인 이후 향강 상세계획이 우선적인 후속 사업으로 추진되었으며, 베트남 정부의 원조사업 요청과 한국 정부의 타당성 조사 절차를 거쳐 2015년도 $\mathrm{KOICA}$ 사업으로 선정되었다.

2015년 1월 사업을 착수하여 현지 워크솝 및 다수의 보고회 개최와 주민 의견 수렴과정 등을 거쳐 상세계획이 수립되었으며, 향강 중심부 보행데크 사업으로 선정된 시범사업은 2017 년 12 월 착공이 예정되어 있다.

향강 사업은 도시 마스터플랜 수립 이후 후에시의 도시 비전과 개발전략을 실현하기 위한 구체적 계획을 수립하고, 실제 시공사업으로 연계된 사업이라는 점에서 의미를 가진다. 
〈그림 11〉 향강 연안 상세계획상의 토지이용계획안, 관광특화 거점사업 구상안

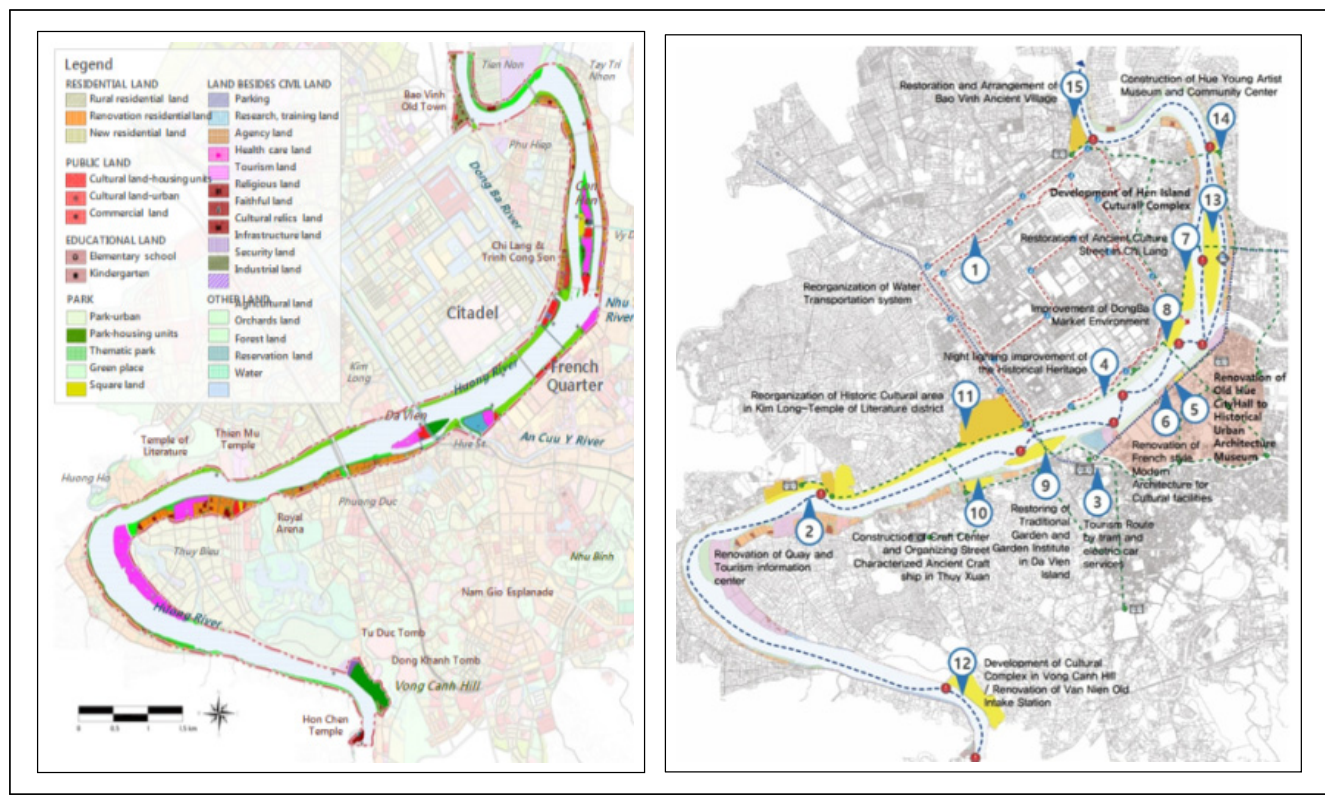

출처: 한국국제협력단 (2017)

〈그림 12〉 향강 남측 도심부 도시설계 및 시범사업 조성 예시도

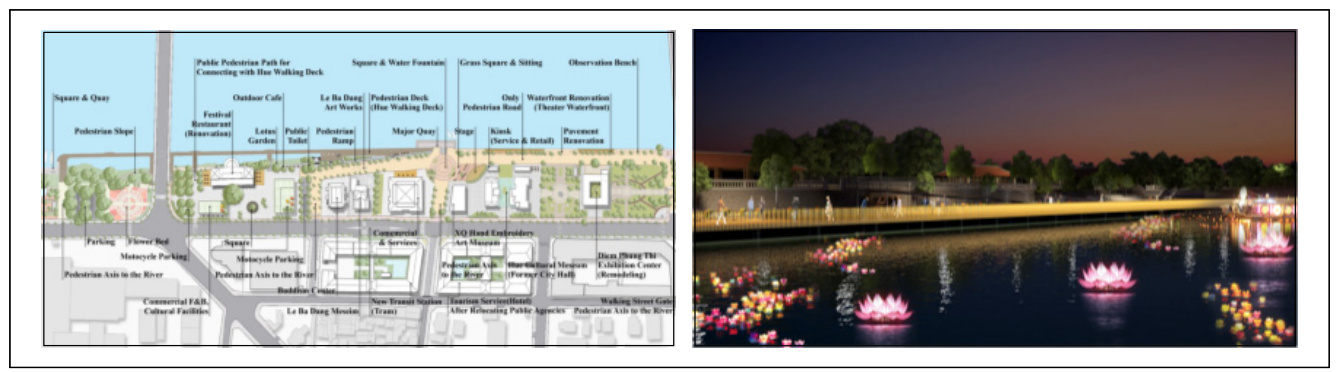

출처: 한국국제협력단 (2017)

\section{2) 다자간 개발은행와의 협력사업: ADB Green Cities Project}

$\mathrm{ADB}$ 의 그린시티(Green Cities) 프로그램은 개발도상국 중소도시(Secondary Cities)의 급속한 도시화에 대응하여 지속 가능한 도시개발을 증진하기 위한 지원 프로그램으로서, 탄소 배출 저감을 위한 대중교통 및 토지이용, 에너지 효율적 인프라, 에너지 절약 및 탄소 배출 저감을 위한 지방정부 정책 수립 등을 지원하고 있다.

$\mathrm{ADB}$ 는 2012년 8월 인도네시아, 말레이시아, 태국 국가를 대상으로 그린시티 컨설팅 프로젝 트 시행하고, 2012년 12월 동남아시아의 지속가능한 도시 미래를 위한 그린시티 프로그램을 
승인하였다. 이후 2013년에는 그린시티 시행을 위한 TA(Technical Assistance) 프로젝트를 발주하고 사업형성을 위한 검토가 추진되었다.

2013년 당시 KOICA 한국 전문가는 후에시 마스터플랜 실행계획 수립을 위해 베트남 내의 다자간 개발은행(Multilateral Development Bank, 이하 MDB)과의 미팅을 추진하였고, $\mathrm{ADB}$ 베트남 사무소와도 협의를 진행하였다. $\mathrm{ADB}$ 의 그린시티 프로그램 담당자는 후에시 마스터플랜의 물리적, 비물리적인 도시 자료 수집 결과와 마스터플랜 수립내용에 대하여 높게 평가하고 $\mathrm{ADB}$ 의 그린시티 프로그램에 본 프로젝트의 결과물을 활용할 수 있도록 요청하였으 며, 동남아시아의 중소도시를 대표하는 그린시티 시범 도시로서 베트남 후에시를 선정하고 인프라 사업투자를 위한 협의를 제안하였다(<그림 $13>$ 참고).

제I장

제II장

섹

포

〈그림 13〉 후에 마스터플랜 자료 요청에 대한 ADB 문서(2013.10), 후에 마스터플랜 사업설명회 개최 당시 ADB의 Green Cities Initiative 발표 사진(2013.11)

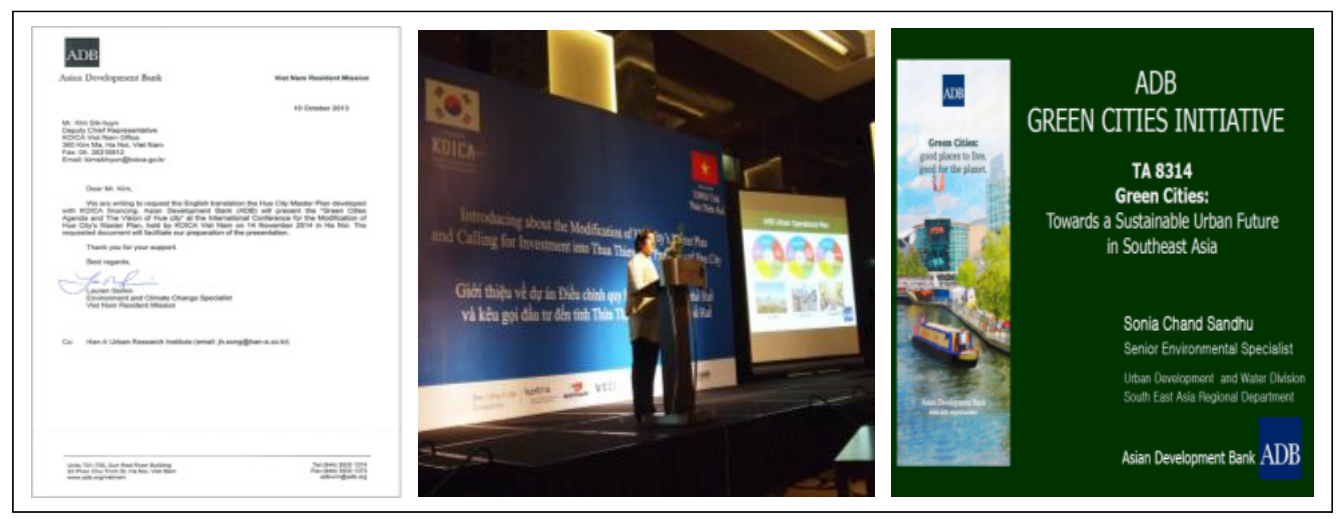

출처: (주)한아도시연구소건축사사무소 (2013)

2014년 ADB는 베트남에서의 Secondary Cities Development Program(Green Cities) 을 최종 승인하고(Project number 47274-001)하고, 후에시를 포함한 베트남의 3개 시범 도시 (Hue, Ha Giang, Vinh Yen)에서 그린시티 실행계획(Green City Action Plans, GCAPs) 수립을 위한 프로젝트를 추진하였다. 2015년 12월 후에시 그린시티 실행계획(Hue GrEEEn City Action Plan) 수립이 완료되었고, 이후 세부 실행사업이 추진되고 있다. 실행계획은 후에 시의 경제성장 기회뿐만 아니라 거주성과 회복력을 향상시키기 위해 도시개발과 환경계획을 통합하여 비전을 달성하는 데 있어 GrEEEn Cities 접근법을 채택하였다. 그린시티 실행계획을 통해 도시환경 개선, 관광 경험 향상, 지속가능한 교통수단 도입이 우선적으로 추진될 예정이다 (<그림 14> 참고). 
$\mathrm{ADB}$ 그린시티 프로그램으로의 확대는 후에시 마스터플랜에서 제안된 공공인프라 조성사업에 다자간개발은행의 투자를 연계하고 이를 통해 계획의 실행 가능성을 높였다는 점에서 시사점을 가진다.

〈그림 14〉 ADB의 후에시 그린시티 액션플랜 (Hue GrEEEn City Action Plan)

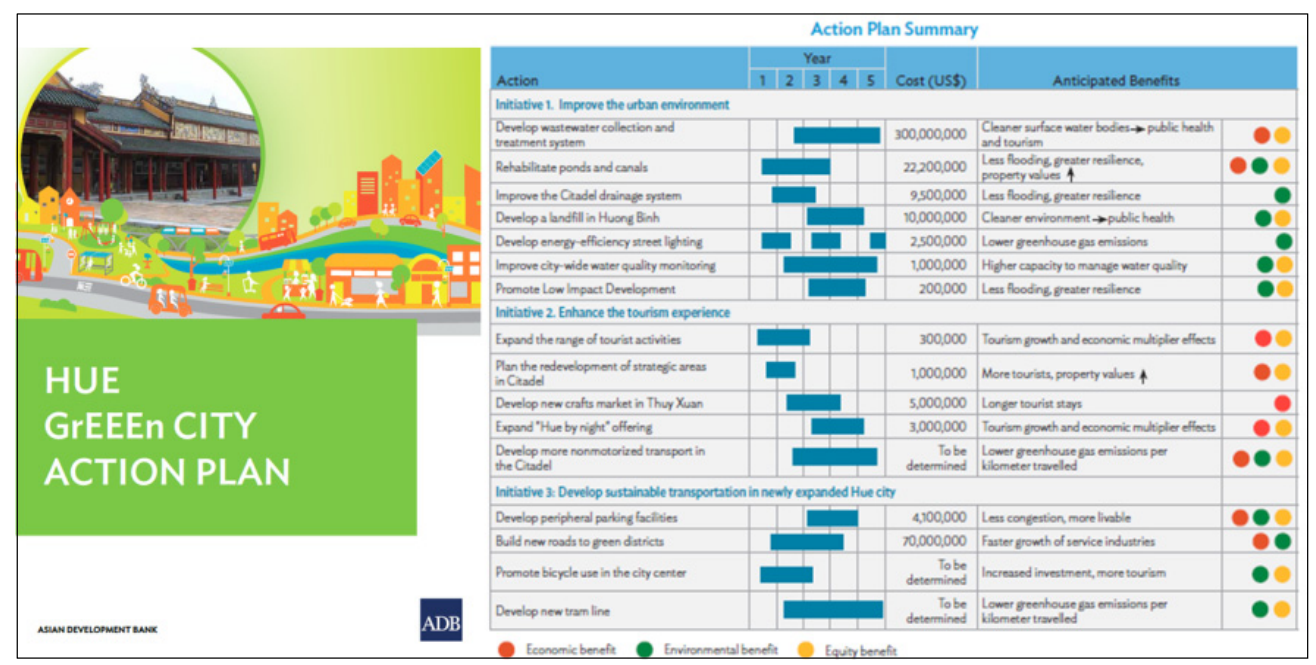

출처: ADB (2015), HUE GrEEEn CITY ACTION PLAN 


\section{IV. 나가며}

앞서 살펴본 SDGs와 도시개발 분야 국내외 ODA 추진 동향, 후속 사업으로 연계된 도시 마스터플랜 사례를 토대로, 도시개발 분야 한국 ODA 사업의 추진 방향을 논의하고자 한다.

\section{SDGs에 부합하는 도시개발 분야 ODA 사업 기획 및 세부전략 수립}

$\mathrm{SDGs}$ 로 전환된 글로벌 개발 의제에 부합하는 도시개발 분야의 ODA 사업 기획과 세부전략 수립이 필요하다. 물리적 개발만을 위한 도시개발에서 나아가 사회적 계획과 결합되고 환경적 지속가능성 향상에 기여하는 사업발굴이 요구된다. 또한, ODA 사업에서 도시개발 분야 지원사 업의 명시적 지향점은 SDGs의 11 번 목표인 “포용적이고 안전하며 회복력 있고 지속가능한 도시와 거주지 조성'이 될 수 있으므로 이를 내재화하는 도시개발 분야의 세부 분야와 추진전략 수립이 필요하다. 구체적으로는 SDG 11의 세부목표와 관련된 적정주택(affordable housin $\mathrm{g}$ )7, 지역·도시계획, 대중교통 시스템, 자연·역사보존, 자연재해·도시재난 대응, 환경오염관리, 공공공간 및 녹지환경 등이 주요 키워드로 검토될 수 있다.

세부 분야 선정에 있어서는 우리나라가 비교우위를 가진 분야를 핵심적으로 검토할 필요가 있다. 예를 들어 급속한 도시화와 경제성장을 토대로 경험을 갖춘 국토·지역·도시계획과 신도시 에 대한 개발컨설팅 분야, 공공주도의 서민주택(social housing), 대중교통 시스템(도시 메트 로, $\mathrm{BRT}$, 무가선트램 등), ICT(통신망 인프라, 정보화 시스템 등) 등은 SDG 11의 세부목표에 부합하면서 우리나라가 강점을 지닌 분야라 할 수 있다. 이중 개발도상국에 적용 가능한 콘텐츠 를 체계화하고 세부전략을 수립하는 것이 필요하다.

다만, 우리나라의 경험을 개발도상국에 적용함에 있어 유의해야 할 사항이 있다. 역사적으로 우리나라를 비롯하여 많은 선진국은 급격한 산업화와 경제성장으로 빠른 도시화를 경험하였으 나, 그 대응방식은 일반화하기 어려울 정도로 다양하고 복잡한 측면을 나타낸다. 이는 도시문제 가 각국의 시대적, 사회적, 구조적 상황에 따라 다양한 해법을 통해 관리, 개선되어 왔다는 것을 보여준다. 우리나라의 경우에도 도시화 문제 대응을 위해 많은 시행착오와 연구를 통해 해법을 고안하고 적용한 경험을 보유하고 있다. 그러나 단기간에 적절한 관리체계를 수립한 우리나라의 경험을 개발 협력 측면에서 성급하게 일반화하여 개발도상국에 전수하려는 시도는 문제를 발생시킬 수 있다. 개발도상국의 경우 각국의 사회적 여건과 상황에 따라 차별화된

7) 중·저소득자를 위한 국가 및 지자체가 정책적으로 지원하는 주택 
문제해결 접근이 필요하다(방설아·신유승, 2015, 한국국제협력단).

또한 기 추진된 도시개발 분야의 ODA 사업에 대해 협력대상국 활용도, 후속연계 현황, 사후평가 결과, 한국기업의 협력대상국 진출 현황 등을 분석하여 향후 도시개발 분야 세부사업 기획 및 수행을 위한 개선안 도출이 필요하다.

\section{ODA 사업의 파급효과를 고려한 지원 대상 지역의 전략적 선정}

한국 무상원조사업이 가장 집중된 지역은 아시아로서 2015년까지의 누적금액 기준으로 가장 많은 지원을 받은 국가는 베트남이다. 베트남은 $\mathrm{KOICA}$ 에서 지원하는 178 개 국가 중 이라크를 제외하고 누적 지원금액 규모가 가장 많은 국가로서, 1991년 2015년 기간 베트남에 지원된 사업금액은 약 2 억 8,000 만 달러이며 KOICA 전체 금액의 약 $5.7 \%$ 에 해당된다. 이는 곧 베트남 에서의 국제개발협력사업 추진이 수월할 수 있음을 의미한다.

앞서 소개한 후에시 마스터플랜 사업의 경우도 지금까지 형성된 한국-베트남 간의 우호 관계를 토대로 타 국가에 비해 추진이 상 대적으로 용이했을 것으로 판단된다. 그 러나 베트남은 무상원조 사업대상에서 제외되는 단계로 접어들어 향후 사업 규 모가 축소될 예정이다. $\mathrm{WB}$ 에서는 이미 2017년 6월 베트남에 대한 협력체계를 변경하여 무상개발원조를 중단하였으며, 민간부문 개발촉진에 초점을 두고 유상개 발원조(차관)을 이행하기로 발표하였다.

ODA 사업추진을 위한 중점협력대상 국과 도시를 선정함에 있어 그 지역의 입 지적 위상과 향후 발전 가능성은 중요한 판단 기준이 된다. 해당 지역이나 국가에 서 전략적 위상을 지닌 도시, 또는 균형발 전 차원에서 전략적 육성이 예상되는 지 역 등은 향후 국제기구나 정부 차원의 집 중적인 투자로 연계될 수 있기 때문이다.

\section{〈그림 15〉 동서경제회랑(EWEC)}

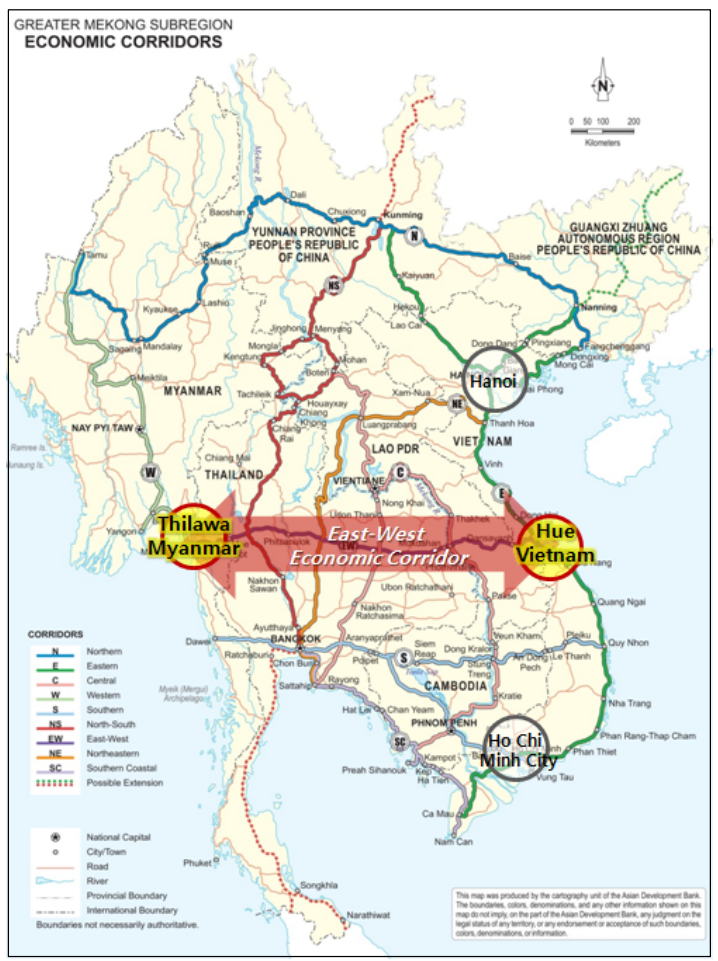

출처: ADB (2010) 참고 저자 작성 
이러한 지역을 대상으로 도시개발 분야의 ODA 사업을 선점적으로 이행할 경우, 사업의 연속성 확보와 파급효과를 기대해볼 수 있을 것이다. 이를 위해서는 향후 개발도상국 국가와 지역, 도시에 대한 면밀한 분석을 기반으로 한 지역 전문성과 도시 분야 전문성을 토대로 입지 선정이 이루어져야 한다.

앞서 소개한 베트남 후에 지역은 $\mathrm{ADB}$ 에서 전략적으로 추진하는 동서경제회랑(East=West Economic Corridor, EWEC)의 동쪽 관문 도시이자, 베트남의 중부지역 균형발전을 위한 6 번째 중앙도시라는 점에서 입지적으로 중요한 지역이라 할 수 있다.

\section{3. 후속 사업 연계 추진에 대한 공공과 민간의 다각적 노력}

급속한 도시화를 경험하는 개발도상국에서 지속가능한 도시개발을 위해서는 도로 및 대중 교통, 상하수도, 에너지공급시설 등 공공인 프라 공급이 필수적인데, 이러한 개발사업 이 진행되기 위해서는 공공이 주체가 되어 도시발전의 틀을 제공하는 도시계획 수립이 선행되어야 한다.

또한, 앞서 살펴본 베트남 후에시 사례와 같이 도시 마스터플랜은 해당 국가 및 도시의 법정계획으로서 실효성 강하며, 공공인프라 뿐만 주택건설, 관광문화 등 다양한 섹터별 계획과 개별 실행사업으로 연계되는 후방 연 계 효과가 큰 특징을 가진다. 즉, 도시 마스터 플랜 사업은 $\mathrm{ODA}$ Tree에서 씨앗 역할 (seed project)을 하는 중요한 사업이라 할 수 있다.

그러나 ODA 사업에서 도시 마스터플랜을

〈그림 16〉 ODA Tree 모식도

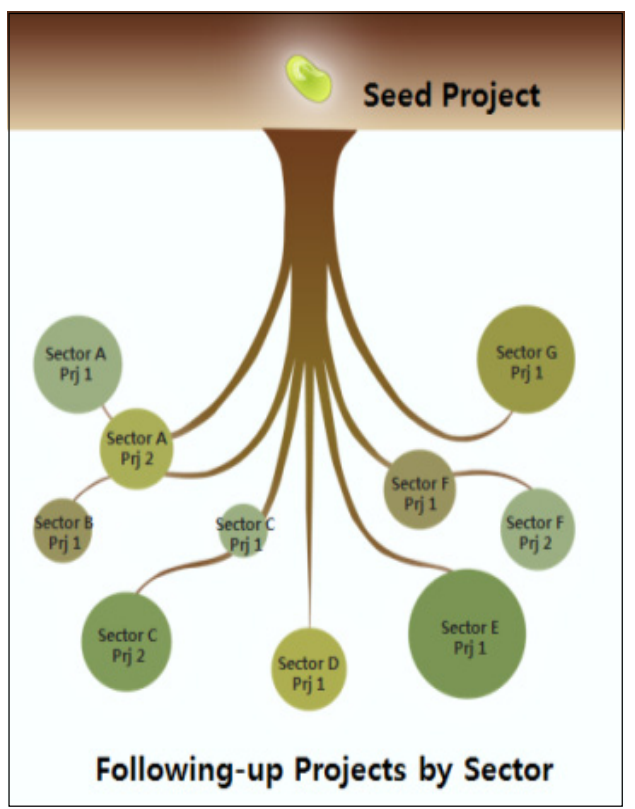

출처: 저자 작성 후속 사업으로 확대하기 위해서는 우리나라 정부 및 $\mathrm{ODA}$ 집행기관, 사업에 참여하는 개발컨설팅 전문가의 역할이 중요하다. 특히 후속 사업에 대해 협력대상국 정부와의 협의를 거치는 과정에서 공공의 신속한 업무지원과 사업추진 의지가 중요하다. 이는 사업 초반 협력대상국 정부의 의사결정 주체와의 협의를 통해 후속 
사업에 대한 방향을 조기 결정하고, 사업화를 위해 필요한 행정절차8)에 대한 신속한 대응과 협조가 필요하기 때문이다.

또한, 지역 기반의 $\mathrm{MDB}(\mathrm{WB}, \mathrm{ADB}, \mathrm{AIB}, \mathrm{IDB}, \mathrm{AfDB}$ 등)를 포함하여 타 $\mathrm{ODA}$ 기관과의 연계 및 네트워크 구축은 보다 다양하고 실행력 있는 후속 사업 형성에 중요한 요소이다. 사업설 명회 등을 통한 사업홍보와 정보제공은 협력대상국 정부와 ODA 기관과의 네트워크를 형성하 고, 민간기업, $\mathrm{NGO}$ 등 다양한 투자 주체와의 연계를 강화하는 데 효과적이다. 이는 도시개발 분야 ODA 사업에 필요한 재원을 조성할 수 있는 개발재원의 다양화와 확보 체계 구축과 연계되어 추진되어야 한다.

8) ODA 사업형성은 협력대상국 지방정부에서 중앙정부로 사업제안서 제출 및 승인 $\rightarrow$ 협력대상국 정부와 한국 정부 간의 협의를 통한 사업선정 단계로 진행된다. 후에시 마스터플랜의 후속 사업인 향강 사업의 경우 베트남 지방정부에서 중앙정부로 제출된 100 여개의 ODA 요청사업 중 10 개 사업이 Short List로 선정되고, 사전타당성 조사 등의 절차를 거쳐 최종적으로 KOICA 사업으로 선정되었다. 


\section{참고문헌}

방설아.신유승. 2015. ${ }^{『} \mathrm{Goal} \mathrm{11-회복력있고} \mathrm{지속가능한} \mathrm{도시와} \mathrm{주거지} \mathrm{조성』.} \mathrm{성남:}$

한국국제협력단.

손동필·오성훈. 2016. 『지속가능발전목표(SDGs) 대비 건축·도시분야 대응방향 연구』.

세종: 건축도시공간연구소.

손동필·조상규. 2015. 『공적개발원조(ODA)를 통한 건축서비스 산업 해외진출 지원 방

안 연구』. 세종: 건축도시공간연구소.

정지원·송지혜. 2014. 『도시의 기후변화 대응을 위한 개발협력: 논의 동향 및 시사점』.

세종: 대외경제정책연구원.

김성호. 2016.『해비타트 3의 주요 비전과 역할』. 서울: 대한지방행정공제회. 최막중. 2016.『해비타트 3의 10 가지 정책 의제』. 서울: 대한지방행정공제회. 한국국제협력단. 2013. 『후에시 마스터플랜 수립 및 개선사업 최종보고서』. 성남: 한국 국제협력단.

2017. 『후에시 향강 연안개발 상세계획 수립 및 시범사업 상세설계 사업 최종초안보고서』. 성남: 한국국제협력단.

홍나미. 2014. “베트남 후에시 마스터플랜 수립 및 개선사업." 도시계획家』제 1 권 제 3 호.

ADB. 2010. 『STRATEGY and ACTION PLAN for the GREATER MEKONG SUBREGION SOUTHERN ECONOMIC CORRIDOR』. Mandaluyong: Asia Development Bank (ADB).

2015. 『HUE GrEEEn CITY ACTION PLAN』. Mandaluyong: Asia Development Bank (ADB).

Nguyen Trung Dzung. 2015. 제3회 아시아법제교류 전문가회의(2015.11.4, 울) 발표 자료.

KOICA 통계조회서비스: http://stat.koica.go.kr (접속일: 2017.11.28.).

아시아개발은행(ADB) 홈페이지: http://www.adb.org (접속일: 2017.11.27.). 